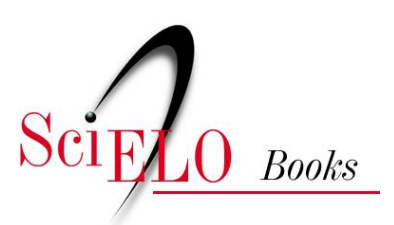

Fiockuz

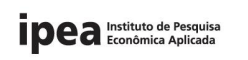

\title{
Doenças transmissíveis, endemias, epidemias e pandemias
}

\author{
Expedito J. A. Luna \\ Jarbas Barbosa da Silva Jr.
}

\section{SciELO Books / SciELO Livros / SciELO Libros}

LUNA, EJA., and SILVA JR., JB. Doenças transmissíveis, endemias, epidemias e pandemias. In FUNDAÇÃO OSWALDO CRUZ. A saúde no Brasil em 2030 - prospecção estratégica do sistema de saúde brasileiro: população e perfil sanitário [online]. Rio de Janeiro: Fiocruz/Ipea/Ministério da Saúde/Secretaria de Assuntos Estratégicos da Presidência da República, 2013. Vol. 2. pp. 123-176. ISBN 978-85-8110-016-6. Available from SciELO Books <http://books.scielo.org>.

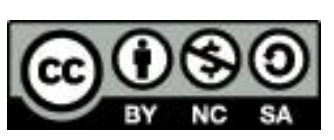

All the contents of this chapter, except where otherwise noted, is licensed under a Creative Commons Attribution-Non Commercial-ShareAlike 3.0 Unported.

Todo o conteúdo deste capítulo, exceto quando houver ressalva, é publicado sob a licença Creative Commons Atribuição Uso Não Comercial - Partilha nos Mesmos Termos 3.0 Não adaptada.

Todo el contenido de este capítulo, excepto donde se indique lo contrario, está bajo licencia de la licencia Creative Commons Reconocimento-NoComercial-CompartirIgual 3.0 Unported. 


\section{Doenças Transmissíveis, Endemias, Epidemias e Pandemias}




\section{DOENÇAS TRANSMISSÍVEIS, ENDEMIAS, EPIDEMIAS E PANDEMIAS}

Expedito J. A. Luna Jarbas Barbosa da Silva Jr.

\section{1 | APRESENTAÇÃO}

Há trinta anos, a emergência da pandemia de HIV/Aids levou ao questionamento dos limites do paradigma então hegemônico, fundado na teoria da transição epidemiológica (OMRAN, 1971) que propunha como modelo para a explicação das tendências contemporâneas de morbidade e mortalidade, a inexorável redução da carga das doenças transmissíveis e sua substituição pelas doenças crônicas não transmissíveis e causas externas.A emergência da Aids demonstrou que esse movimento não ocorreria de forma linear, e que os mesmos fatores relacionados ao desenvolvimento socioeconômico e a modernidade, que seriam os determinantes da transição epidemiológica, também poderiam produzir processos na direção inversa, propiciando o surgimento, a modificação de padrão e a disseminação de novas e velhas doenças infecciosas, configurando um perfil epidemiológico complexo. A partir dessa evidência, surge o conceito das doenças infecciosas emergentes e reemergentes, que seriam aquelas cuja incidência em humanos vem aumentando nas últimas duas décadas ou ameaça aumentar num futuro próximo (CDC, 1994).

O conceito, apesar de pouco preciso, incorpora claramente dois focos principais: o surgimento de novos problemas de saúde relacionados a novos agentes infecciosos; e a mudança de comportamento epidemiológico de velhas doenças infecciosas, incluindo a introdução de agentes já conhecidos em novas populações de hospedeiros suscetíveis e outras alterações importantes no seu padrão de ocorrência. Esses fenômenos da emergência e reemergência de doenças infecciosas estão relacionados a diversos fatores, desde as profundas e rápidas mudanças que têm ocorrido em aspectos demográficos, socioeconômicos e ambientais, além daqueles relacionados ao desempenho do setor saúde, das mudanças e mutações nos microrganismos, até a possibilidade de manipulação de agentes infecciosos com vistas ao desenvolvimento de armas biológicas. O próprio desenvolvimento tecnológico tem possibilitado a 
participação de agentes infecciosos em patologias tidas, até recentemente, como "crônico-degenerativas", a exemplo do câncer de colo de útero e úlcera estomacal, entre outras (INSTITUTE OF MEDICINE, 1992 e 2003).

A mensagem central na construção do conceito das doenças emergentes e reemergentes parece ser a constatação de que a convivência da espécie humana com os agentes infecciosos, em um ambiente continuamente modificado pela ação humana, fez, faz, e continuará a fazer parte da experiência da vida no planeta, e que as doenças infecciosas e seus agentes continuarão em seu movimento, em direção ao controle, eliminação e eventualmente, erradicação, mas também com a possibilidade de percorrerem a direção oposta, emergindo ou reaparecendo, em determinadas situações.

Ao analisarem a situação da América Latina, alguns autores depararamse com as limitações da teoria original da transição epidemiológica. Apesar de ser uma região relativamente homogênea, um quadro mais complexo do que o habitualmente reconhecido por aquela teoria emergia na análise dos padrões de mortalidade e morbidade do subcontinente. Observava-se um quadro de grande heterogeneidade entre os países, e mesmo no interior de cada país. Alguns países estariam em uma etapa mais avançada do modelo clássico da transição proposto por Omran (Cuba, Costa Rica, Chile) (OMRAN, 1971 e 1983), outros estariam apenas iniciando o processo de transição (Haiti, Bolívia), e outros ainda apresentariam características tão distintas que configurariam um “novo modelo de transição", que teria como exemplos paradigmáticos o México e o Brasil. Três características distinguiriam estes países:

- sobreposição de etapas - doenças infecto-parasitárias e crônicodegenerativas com grande importância absoluta e relativa;

- um movimento de "contratransição", representado pelo ressurgimento de doenças como a malária, o cólera e a dengue, com grande importância na morbidade, mas sem grande interferência na mortalidade; e

- uma "transição prolongada", pois não há uma expectativa clara de resolução do processo de transição, que cursaria com uma exacerbação das desigualdades dentro dos países.

Estas características distinguiriam na América Latina um novo modelo da transição epidemiológica, o "modelo polarizado prolongado" (FRENK, 1991). Outros autores, ao analisarem especificamente a situação brasileira, também apontam para um modelo diferente e muito mais complexo de transição epidemiológica (ARAÚJO, 1992; REICHENHEIM \& WERNECK, 1994; BARRETO \& CARMO, 2007).

Nesse contexto, será feita uma análise geral da situação atual das doenças 
transmissíveis no Brasil, com o propósito de, na medida do possível, projetar cenários para a próxima década, quando o país comemorará o bicentenário de sua independência. Para a realização desta tarefa, foi feita revisão da literatura especializada, consulta às publicações do Ministério da Saúde, e quando necessária, a análise dos bancos de dados dos sistemas nacionais de informações em saúde. Será feita uma análise sucinta da situação atual das doenças infecciosas e parasitárias no país, com o objetivo de identificar suas principais características e tendências. Pela própria natureza desse texto, não se pretende uma análise exaustiva sobre todas as dimensões dessas doenças e das políticas e estratégias utilizadas para sua prevenção e controle.

Em seguida, será discutida a situação atual e feita a projeção de cenários futuros para algumas doenças e quadros sindrômicos selecionados, que serão agrupados em três grandes grupos: doenças com tendência ao declínio em sua incidência, prevalência e mortalidade, doenças que vem apresentando uma estabilização em seus indicadores de ocorrência, e as doenças emergentes e reemergentes. Essa classificação não se pretende estanque porque há situações epidemiológicas que a transcendem, com manifestações de uma mesma doença apresentando comportamentos que a situariam, simultaneamente, no primeiro e no terceiro grupos, como na doença de Chagas transmitida por vetores e por transmissão oral, ou ainda na tuberculose e em sua variante multidroga resistente, Serão também discutidos aspectos relacionados às intervenções voltadas a prevenção e controle das doenças transmissíveis, bem como a resposta brasileira à demanda internacional de aprimoramento na capacidade de detecção, investigação e resposta às doenças e situações com potencial ameaça de disseminação internacional. A discussão de cenários futuros será feita a partir da análise das séries históricas de ocorrência das doenças e do desempenho e eficácia das intervenções de controle disponíveis. Não foram utilizados modelos matemáticos na proposição de cenários futuros.

\section{2 | SITUAÇÃO ATUAL: MORTALIDADE E MORBIDADE POR DOENÇAS INFECCIOSAS NO BRASIL}

É inequívoca a redução absoluta e relativa da mortalidade por doenças infecciosas e parasitárias (DIP) no Brasil ao longo do século XX, produzida tanto por fenômenos como a urbanização, melhoria das condições de vida, maior acesso ao saneamento e outros determinantes sociais, como pela incorporação de tecnologias como as vacinas, antibióticos e antivirais, e pelo maior acesso aos serviços de saúde, particularmente aos de atenção primária.

A mortalidade proporcional por este grupo de doenças caiu de 45,7\% do total de óbitos nas capitais do país em 1930, para 4,2 \% do total de óbitos registrados em 2011, variando de 3,6\%, na Região Sul até 5,4\%, no Norte (BRASIL, 2012a). 
Nas últimas três décadas, observou-se redução importante na mortalidade por diarreias, por doenças preveníveis por vacinação, e por infecções respiratórias em crianças. A taxa de mortalidade por tuberculose reduziu-se em 33,3\%, entre 1990 e 2012, de 3,6 para 2,4 por 100.000 hab. O número de óbitos devido à malária também se reduziu de forma importante, nesse mesmo período, de 927 para 58, um decréscimo de 93,7\%. A doença de Chagas, que produzia cerca de 100.000 casos novos por ano, na década de 1970, teve sua transmissão pelo principal vetor, o T. infestans, interrompida em 2006, emergindo, nos anos recentes, como doença de transmissão por alimentos, principalmente na Região Norte. Nesse período, a Aids passa a ocupar o posto de principal causa de mortalidade entre as doenças infecciosas, com cerca de 12.000 óbitos, nos anos recentes. A dengue também passa a registrar óbitos com mais frequência a partir do final dos anos 1990 e início dos anos 2000, em decorrência da circulação sucessiva de distintos sorotipos. Mesmo com essa situação, e na emergência de circulação de um novo sorotipo, o DENV 4, a partir de 2011, observa-se uma redução no número de casos graves e óbitos (BRASIL, 2012a e 2013a).

Atualmente, uma proporção importante dos óbitos por doenças infecciosas é representada pelas infecções respiratórias em adultos. Segundo Barreto e col."a distribuição das causas de morte por doenças infecciosas mudou na direção de um padrão mais próximo do observado em países desenvolvidos, especialmente no que se refere à predominância de pneumonia em populações adultas e idosas" (BARRETO, et al, 2011).

Em análise realizada a partir dos dados de mortalidade do ano de 2004, não houve diferença na proporção de óbitos por doenças infecciosas e parasitárias entre a população brasileira em geral, e a parcela usuária de planos de saúde privados (SASSON, et al, 2013).

As recentes incorporações a o programa de vacinação universal de crianças, da vacina contra Haemophilusinfluenzae tipo B, rotavírus, da vacina pneumocócica conjugada 10 valente e da vacina meningocócica C conjugada, fazem prever uma redução ainda mais acentuada na mortalidade por diarreias, pneumonias e doença meningocócica em crianças, nos próximos anos.

A mortalidade por doenças infecciosas e parasitárias apresenta uma persistente tendência de redução nas últimas décadas, embora, como consequência dos valores cada vez menores que vem alcançando recentemente, o ritmo dessa redução venha se desacelerando nos anos mais recentes. A expectativa para a próxima década é de manutenção dessa tendência, que poderá se alterar apenas com o surgimento de avanços tecnológicos capazes de produzir um alto impacto nessa mortalidade. A reversão dessa tendência poderá ocorrer apenas em um cenário de emergência de problemas com alta severidade e letalidade. 
Em relação à morbidade, verifica-se que a proporção de internações hospitalares decorrentes de doenças infecciosas e parasitárias no SUS vem se mantendo relativamente constante nos últimos quinze anos, ficando em torno de 9\% das internações hospitalares registradas no Sistema de Informações Hospitalares do SUS (SIH-SUS). Os principais responsáveis por essas internações continuam a ser as infecções respiratórias e as gastroenterites (BARRETO \& CARMO, 2007).

Analisando-se a série histórica das doenças de notificação compulsória registradas nas últimas duas décadas, observa-se que as sucessivas epidemias de dengue são as responsáveis pela grande maioria dos registros, seguidas pelos casos de malária, ainda muito frequentes, apesar da tendência de redução, na região Amazônica.

\section{3 | DOENÇAS INFECCIOSAS E PARASITÁRIAS COM TENDÊNCIA DE FORTE DECLÍNIO EM SUA OCORRÊNCIA OU PERSPECTIVA DE ELIMINAÇÃO}

Neste grupo de doenças, incluem-se aquelas preveníveis por vacinação, as diarreias, a doença de Chagas, a esquistossomose, a raiva humana, as hepatites A e B, a filariose linfática, e a oncocercose.

\section{1 | Doenças imunopreveníveis}

O Brasil vem apresentando um notável desempenho em relação ao controle das doenças preveníveis por vacinas. Especialmente a partir da segunda metade da década de 1990 vem se observando uma tendência de redução da incidência desse grupo de doenças, em paralelo ao aumento das coberturas vacinais. O Programa Nacional de Imunizações (PNI) foi criado em 1973, no momento dos esforços finais para a erradicação da varíola, porém o grande marco na ampliação do seu escopo e visibilidade deu-se com a implantação da estratégia dos Dias Nacionais de Vacinação contra a Poliomielite, em 1980. O resultado da nova estratégia foi quase que imediato, com uma redução de 90\% na incidência de poliomielite entre 1980 e 1981. Em 1989 foram registrados os últimos casos de poliomielite paralítica pelo poliovírus selvagem no Brasil, e em 1993 o país recebeu da Organização PanAmericana de Saúde (OPAS/OMS) a certificação da interrupção da transmissão no país. Como etapa final no processo de erradicação da doença, o País iniciou a substituição da vacina oral de vírus vivos atenuados (VOP ou vacina Sabin) pela vacina de vírus inativados (também conhecida como vacina Salk), pois com esta vacina será eliminado o risco, ainda que muito baixo, da ocorrência de casos de poliomielite induzidos pelo vírus vacinal, bem como a possibilidade de circulação de vírus derivados dos vírus vacinais em populações não vacinadas, o que pode levar a reversão à virulência dos vírus vacinais, como já relatado no Haiti, Egito, Indonésia, 
Nigéria e em outros países que passaram por quedas em suas coberturas vacinais com a VOP (KEW et al, 2005).

Em 1994 foi estabelecida a meta de interrupção da transmissão do sarampo no Continente Americano. O Brasil implantou gradativamente, entre 1992 e 2000, a vacina tríplice viral (SRC - sarampo, caxumba e rubéola), tendo realizado em 1992 a primeira campanha de vacinação contra o sarampo, o que produziu uma queda importante na incidência da doença. Porém, por conta da não adesão de alguns estados à campanha de vacinação subsequente prevista na estratégia, uma nova epidemia de sarampo voltou a ocorrer no Brasil em 1996-1997, a partir de casos importados da Europa. A estratégia de interrupção da transmissão foi retomada, e no ano 2000 ocorreram os últimos casos de sarampo de transmissão autóctone no país. No período posterior, vem sendo observada apenas a ocorrência de casos importados de sarampo, sem transmissão autóctone. De forma semelhante, foi estabelecida em 2003 a meta de eliminação da rubéola e da síndrome da rubéola congênita (SRC) em 2010. O Brasil realizou em 2002 uma grande campanha de vacinação contra rubéola das mulheres em idade fértil, e em 2008 uma campanha ainda mais ampla, incluindo jovens e adultos, de ambos os sexos, até 39 anos de idade. Foram vacinadas mais de 68 milhões de pessoas, atingindo uma cobertura vacinal de 96\%. Desde 2009 não houve mais casos confirmados de rubéola no país. A incidência de SRC também caiu após a última campanha de vacinação (TOSCANO et al, 2010). O desafio que permanecerá para essas doenças, cuja interrupção da transmissão ocorreu apenas regionalmente, é manter altas e homogêneas coberturas vacinais, ao lado de uma vigilância sensível para detectar oportunamente e tomar as correspondentes medidas de contenção, diante dos casos importados que, inevitavelmente, continuarão a ocorrer pelo crescente número de viajantes internacionais, enquanto a doença não for eliminada globalmente.

As doenças preveníveis pelas vacinas tríplice bacteriana e tetravalente (a difteria, o tétano, a coqueluche e as infecções pelo Haemophylus influenzae tipo B) também apresentam redução importante em sua incidência. O Brasil já atingiu a meta de eliminação do tétano neonatal como problema de saúde pública (incidência < 1 caso para 100.000 nascidos vivos), porém um pequeno número de casos ainda continua a ser notificado a cada ano (menos de 10 casos/ano, entre 2006 e 2010), principalmente no Norte e Nordeste, evidenciando problemas com a cobertura e qualidade dos serviços de atenção pré-natal nessas regiões. A incidência de tétano acidental caiu em mais de $80 \%$ entre 1990 e 2009, porém o país continua a registrar mais de 300 casos ao ano, em virtude da existência de uma importante proporção de adultos não vacinados na população.

Até 1999, ano da introdução da vacina contra Haemophylus influenzae tipo B no programa de vacinação universal, eram notificados cerca de 1.700 casos anuais de meningites por esta bactéria, com uma incidência média anual de 1,1 casos por 100.000. Após a introdução da vacina, observou-se uma queda superior a 90\% na incidência da 
doença. Entre 1990 e 2009 a redução na incidência de difteria também foi superior a 90\%. O número de casos confirmados tem se mantido abaixo de 10 casos anuais. A redução na incidência de coqueluche também foi da ordem de 90\% no mesmo período, porém o país ainda convive com cerca de 1.000 casos anuais da doença. A maioria deles entre menores de um ano. A persistência de um número expressivo de casos de coqueluche sugere a existência de um pool de portadores sadios do agente etiológico, entre os adultos jovens, e a transmissão aos menores de um ano de idade, antes da vacinação ou antes do término da série de três doses da vacina, aplicadas no primeiro ano de vida.

A partir de 2011 vem se observando um aumento na incidência de coqueluche no Brasil. De forma diferente ao aumento também observado em outros países, como nos Estados Unidos, Reino Unido, Nova Zelândia e Austrália, onde o grupo mais atingido foram os adolescentes, no Brasil o grupo de menores de um ano concentra 70\% dos casos. Para responder a essa situação, o Ministério da Saúde programou a introdução da vacina tríplice bacteriana acelular (DTPa) para gestantes, a partir de 2013.

A primeira vacina contra hepatite B, produzida a partir de antígeno isolado de plasma humano, tornou-se disponível no mercado em meados da década de oitenta do século passado. Ao final da década, foram lançadas as vacinas recombinantes. 0 Brasil começou a usá-las, já ao final da década de 1980, em estratégias de campanhas, cujo alvo foram as regiões do país consideradas de alta endemicidade, como a Amazônia Ocidental (FIGUEIREDO, 2006). Só a partir de 1999 a vacina contra hepatite B foi incorporada ao calendário de vacinação universal de crianças. Se por um lado, o número de casos notificados apresenta tendência ao aumento no período 19902009, por outro, os resultados do inquérito nacional de prevalência de hepatites virais, coordenado pelo Ministério da Saúde, revelaram níveis de prevalência inferiores aos esperados na amostra representativa das capitais dos estados e Distrito Federal. A prevalência nacional de portadores do HBsAg foi de 0,37\% (IC 95\%: 0,25-0,50), sendo mais elevada nas capitais dos estados da Região Norte (0,63\%; IC 95\%: 0,22-1,04) (XIMENES et al, 2010). A vacina contra hepatite B é aquela com menores níveis de cobertura vacinal, dentre as vacinas do calendário básico de vacinação da criança. Além disso, a cobertura da primeira dose nas primeiras 48 horas de vida, procedimento recomendado para a prevenção da transmissão da mãe para o recém-nascido ainda era inferior a 50\% em 2007, indicando que os potenciais benefícios desta vacina ainda não foram completamente atingidos no país (LUNA et al, 2009).

Em março de 2006, o Brasil incorporou a vacina oral contra rotavírus ao programa de vacinação universal de menores de um ano. O país vem utilizando a vacina monovalente de rotavírus humanos rearranjados. Em virtude da possibilidade de indução de eventos adversos, vem-se observando um aprazamento rígido em relação à idade de administração das doses da vacina: a primeira, entre 6 e 13 semanas, e a 
segunda entre 13 e 22 semanas. Em consequência, a cobertura vacinal com a segunda dose tem-se mantido em torno de $80 \%$ nos quatro anos da série. Apesar da cobertura não chegar a ser tão alta como as demais vacinas, análise recente apontou para uma redução de 22 \% na mortalidade e de 17\% nas internações hospitalares por diarreias na população menor de cinco anos de idade nos três primeiros anos (2007 - 2009) após a introdução da vacina (CARMO et al, 2011).

\subsection{Pneumonias e Influenza}

A análise da série histórica de mortalidade por infecções respiratórias nas últimas três décadas evidencia uma redução da mortalidade proporcional por infecções respiratórias em crianças, e um aumento entre os adultos, convergindo para um padrão semelhante ao dos países desenvolvidos (BARRETO et al, 2011). Provavelmente essa tendência relaciona-se à ampliação da cobertura de serviços de saúde, e à melhoria das condições de vida. Entre 2007 e 2009 74\% dos óbitos por pneumonias ocorreram nos maiores de 60 anos (TOSCANO et al, 2010). Por outro lado, desde 1999 o país vem realizando campanhas anuais de vacinação contra influenza, inicialmente voltadas à população maior de 60 anos e profissionais de saúde, tendo sido incorporados, progressivamente novos grupos vulneráveis. Em 2013 serão alvo da vacinação os maiores de 60 anos, as mulheres grávidas e puérperas, crianças dos seis meses a menores de dois anos, prisioneiros, indígenas, trabalhadores da saúde e portadores de doenças crônicas que aumentam os riscos para complicações da gripe (BRASIL, 2013b). As coberturas vacinais entre os maiores de 60 anos vêm se mantendo em patamar elevado, tendo sido atingida a meta mínima de 70\% de cobertura vacinal em todos os anos da série, exceto no ano 2000. Apesar das altas coberturas, os efeitos em termos de redução da mortalidade e morbidade por doenças respiratórias não têm sido tão evidentes.

Os estudos ecológicos que tentaram apreender os efeitos das campanhas de vacinação apresentam resultados conflitantes, alguns apontando para uma redução discreta da mortalidade e internações hospitalares em algumas regiões do país, outros não demonstram efeito algum, e outros ainda identificam um aumento nas causas de morte e internações hospitalares relacionadas à influenza (DAUFENBACH et al, 2009; CAMPAGNA et al, 2009; LUNA \& GATTÁS, 2010). Esses resultados aparentemente discordantes são coerentes com avaliações semelhantes realizadas internacionalmente e expressam, em grande medida, características da própria vacina de influenza. Parte desta dificuldade em aferir a efetividade das campanhas de vacinação pode ser creditada à inespecificidade dos desfechos, uma vez que a maioria dos estudos trabalha com causas de morbidade e mortalidade relacionadas à influenza, pois o diagnóstico etiológico das infecções respiratórias não é realizado de forma rotineira pelos serviços de saúde. Entretanto, uma questão fundamental que se deve levar em conta é a 
grande variabilidade da eficácia apresentada pela vacina de influenza de um ano para outro, que sempre é limitada e pode ser muito baixa, ou quase inexistente, em alguns invernos, como apontado em amplas revisões realizadas recentemente (OSTERHOLM et al, 2012). Esse comportamento é relacionado com as próprias limitações inerentes à vacina atualmente utilizada, que pode proteger de maneira diferente para cada um dos sorotipos que a integram, e a possibilidade de circulação de sorotipos mais severos em determinados anos. Considere-se ainda, que em alguns anos a intensificação da ocorrência de casos de Síndrome Respiratória Aguda Grave (SRAG) por influenza e de óbitos por infecções respiratórias na região Norte e em parte da região Nordeste pode ocorrer em períodos anteriores ao da disponibilidade da vacina para o Hemisfério Sul, pois nessas regiões não há um pico concentrado da transmissão no inverno, diferente do observado nas regiões Sul, Sudeste e Centro-Oeste (ALONSO et al, 2007).

\section{3| Doenças Diarreicas}

Desde a década de 1980 o país vem observando a queda na mortalidade por doenças diarreicas. A disseminação do uso da terapia de reidratação oral e a ampliação da cobertura de serviços de atenção primária vêm sendo apontados como os principais fatores internos ao setor Saúde associados a este declínio (VICTORA et al, 1996). A incidência das diarreias também declinou no período, em paralelo à ampliação das redes de abastecimento de água e esgotamento sanitário (BARRETO et al, 2007). Foi demonstrada também a mudança no perfil dos agentes etiológicos das gastroenterites, da predominância de agentes bacterianos de transmissão fecal-oral para os agentes virais, cuja transmissão se dá também pela via interpessoal (BARRETO et al, 2006).

\subsection{Hepatite A}

Os resultados do inquérito nacional de prevalência de marcadores sorológicos de hepatites virais revelaram uma prevalência de 39,5\% de portadores de marcadores sorológicos de hepatite A na população de 5 a 19 anos de idade das capitais dos estados brasileiros e Distrito Federal, o que coloca o país na faixa considerada como de baixa endemicidade. As capitais dos estados das regiões Norte, Nordeste e Centro-Oeste estão na faixa de média endemicidade. Estes níveis de prevalência são significativamente mais baixos do que os observados em inquéritos realizados na década de 1980. Provavelmente, a ampliação da cobertura das redes de abastecimento de água e esgotamento sanitário contribuiu para a redução da transmissão e da prevalência de marcadores de infecção pregressa, tendência que deve prosseguir nos próximos anos (XIMENES et al, 2008). 


\subsection{Esquistossomose}

Até a década de 1970 a esquistossomose era endêmica na maior parte dos estados das regiões Nordeste e Sudeste. O programa de controle, centrado no tratamento em massa, foi implantado no país em 1975, de forma vertical, descentralizado para os estados na década de noventa, e posteriormente para os municípios. A maioria dos estudos vem demonstrando uma redução consistente nas taxas de detecção da doença. Verifica-se também uma redução nas internações hospitalares e nos óbitos por esquistossomose (BRASIL, 2012b). No estado de São Paulo, uma redução superior a 90\% foi observada no número total de casos detectados e no número de casos autóctones, entre 1981 e 2009 (SÃO PAULO, SES, 2011).

A ampliação da cobertura do saneamento básico, aliada às maiores possibilidades de tratamento, e à diminuição da população rural do país parecem estar relacionadas a esta redução na ocorrência da doença, que, entretanto, ainda persiste, de maneira focalizada, em comunidades, principalmente rurais e periurbanas, em 19 estados brasileiros (BRASIL, 2012b). Com o lançamento do "Plano integrado de ações estratégicas de eliminação da hanseníase, filariose, esquistossomose e oncocercose como problema de saúde pública, tracoma como causa de cegueira e controle das geohelmintíases: plano de ação 2011-2015", a adoção de um patamar de prevalência mais baixo para a adoção do tratamento coletivo, 25\% ao invés dos 50\% anteriores, o que representou, na prática, uma retomada dessa estratégia que estava praticamente abandonada nos anos recentes e a integração com outras ações de combate às doenças relacionadas com a pobreza, realizada em 2011, poderá acelerar a eliminação desses focos de esquistossomose (BRASIL, 2012b).

\subsection{Doença de Chagas}

Até a década de setenta a tripanossomíase americana era endêmica em 18 estados brasileiros. A soroprevalência, em inquérito realizado entre 1975 e 1980, era de 4,2\% (BRASIL, 2009a). Em 1975 foi implantado o programa de controle, centrado na erradicação do principal vetor da enfermidade, o inseto hematófago Triatomainfestans (BRASIL, 2005a). Em 2006 o país teve a interrupção da transmissão por esse vetor certificada pela Organização Pan-Americana da Saúde (OPAS\OMS) (SILVEIRA \& DIAS, 2011). A prevalência da doença em crianças foi de 0,03\% no último inquérito nacional, realizado durante a década de 2000, sem nenhum caso identificado como de transmissão vetorial (OSTERMAYER et al, 2011). A transmissão transfusional também foi controlada a partir de meados da década de 1990 (MORAES-SOUZA \& FERREIRASILVA, 2011). Entretanto, vale ressaltar que se estima a existência de 3,5 milhões de portadores da forma crônica da doença de Chagas, infectados nas décadas passadas, e que representam uma importante demanda por assistência especializada. Com a 
interrupção da transmissão vetorial e o controle da transmissão pelo uso de transfusões de sangue e derivados, adquiriu destaque a transmissão alimentar, especialmente na Região Amazônica, onde tem produzido surtos limitados, geralmente familiares. A transmissão alimentar relaciona-se à contaminação de alimentos, em especial frutas e preparados a partir destas, com o agente etiológico, vinculado ao ciclo zoonótico, no qual estão envolvidos marsupiais da fauna silvestre brasileira e triatomíneos de hábitos silvestres. A doença de Chagas de transmissão alimentar é considerada uma zoonose reemergente no Brasil e em outros países das Américas. Dos 945 casos de doença de Chagas aguda notificados no país entre 2000 e 2009, 78\% tiveram o modo de transmissão determinado, e destes 97,5\% ocorreram por transmissão alimentar. Mais de 90\% desses casos ocorreram na região Amazônica, onde o principal alimento envolvido na transmissão é a pasta de açaí (BRASIL, 2010a).

\section{7 | Raiva Humana}

Desde a década de 1980 o Brasil realiza campanhas anuais de vacinação de cães e gatos contra a raiva, com o propósito de eliminar a raiva humana. O número de casos de raiva entre cães e gatos tem decaído consistentemente durante a última década e o número de casos humanos por agressões destes animais tem sido inferior a 10 por ano. Em 2008, nenhum caso de raiva humana transmitida no ciclo urbano foi notificado. Esta redução é decorrente da realização das campanhas de vacinação animal e do programa de tratamento profilático de pessoas agredidas por animais. O número de tratamentos humanos tem aumentado na última década, chegando a mais de meio milhão de pessoas nos últimos anos da série. 95\% dos casos referem agressão por cães ou gatos (BRASIL, 2010b). Esse aumento pode representar, também, a melhora no registro desses dados. Em paralelo à redução da ocorrência de casos de raiva humana no ciclo urbano, o país assistiu na última década a emergência do ciclo silvestre da doença, envolvendo populações rurais da Região Amazônica e do seu entorno, e agressões por animais silvestres, notadamente os morcegos hematófagos (BRASIL, 2004 e 2006a). Desde 2004 o número de casos humanos relacionados ao ciclo silvestre tem sido superior aos casos no ciclo urbano. A raiva em seu ciclo de transmissão silvestre é considerada uma doença reemergente no Brasil.

\subsection{Filariose linfática}

Apenas um único foco de transmissão da Wuchereria bancrofti permanece ativo no país, a Região Metropolitana do Recife, envolvendo quatro municípios (BRASIL, 2009b). A partir da implantação de estratégias adequadas, como o tratamento coletivo em áreas hiperendêmicas, a partir de 2003, foram obtidos resultados positivos na redução sustentada da transmissão da doença, com queda na taxa de positividade, atingindo-se uma prevalência de apenas 0,03\%, entre mais de 100 mil pessoas residentes 
em área de risco submetidas ao exame parasitológico (BRASIL, 2012b). Mantida essa tendência, com o reforço da meta de eliminação a partir do Plano Integrado lançado em 2011 pelo Ministério da Saúde, a filariose estará eliminada do país nos próximos anos, provavelmente antes de 2020, meta que foi estabelecida pela OMS (WHO, 2000).

\subsection{Oncocercose}

A ocorrência de oncocercose está restrita ao extremo norte do país, na região da fronteira com a Venezuela, onde vive o povo Yanomami. A população em risco é estimada em 15.000 habitantes. O programa de tratamento em massa, visando à interrupção da transmissão, vem obtendo cobertura acima de 85\% desde 2001, e uma redução significativa da prevalência vem sendo observada (BANIC et al, 2009), colocando a perspectiva da próxima eliminação da doença no território brasileiro. Alcançada essa meta, persistirá a necessidade de manter a vigilância pós-eliminação (BRASIL, 2012b).

\section{4 | DOENÇAS QUE APRESENTAM REDUÇÃO EM SUA CARGA, MAS QUE AINDA PERSISTEM COMO PROBLEMA DE SAÚDE PÚBLICA}

Neste grupo de doenças incluem-se aquelas que apresentam tendência de estabilidade nos indicadores de morbimortalidade ou que têm tido a sua carga reduzida, porém ainda persistindo como problema importante de saúde pública no país, como a hanseníase, a tuberculose, o tracoma, a malária, a doença meningocócica, as geohelmintíases, a cisticercose, a toxoplasmose, a febre tifoide, a sífilis e outras doenças sexualmente transmissíveis, a peste, a varicela, as micoses sistêmicas e a hidatidose.

\subsection{Hanseníase}

O Brasil foi um dos poucos países do mundo, dentre aqueles com mais de um milhão de habitantes, a não atingir a meta internacionalmente pactuada de eliminação da hanseníase enquanto problema de saúde pública até o ano 2000, pela lentidão com que foram adotadas, nos anos 1980 e 1990, estratégias eficazes como a introdução do esquema terapêutico combinado, conhecido como poliquimioterapia (PQT) e a integração do programa com a atenção primária de saúde, entre outras razões. Com a introdução da PQT a partir da segunda metade da década de oitenta, os níveis de prevalência decaíram em mais de 80\%, até o final da década passada. Entretanto, a taxa de detecção aumentou até a primeira metade da década de 2000, e apenas no período mais recente inicia-se uma tendência sustentada de queda deste indicador. 
Apesar de algumas análises terem especulado sobre a queda na detecção observada em 2005 dever-se a problemas no sistema de informações, estudos mais consistentes têm demonstrado que essa tendência à redução na taxa de detecção vem se mantendo desde então, mesmo com os esforços e iniciativas realizados para aumentar a busca de casos (PENNA et PENNA, 2007).

O coeficiente de prevalência de hanseníase do Brasil era 1,54 casos/10 mil habitantes em 2011, o que aproxima o país da meta de eliminação enquanto problema de saúde pública e representa uma redução de 61,4\% em relação a 2001, quando a prevalência era de 3,99 por 10.000 hab. Persiste, entretanto, uma importante desigualdade regional, pois, enquanto todos os estados da região Sul, Minas Gerais, Rio de Janeiro, São Paulo, Alagoas e Rio Grande do Norte já alcançaram prevalência menor que 1 caso por 10.000 hab., em Mato Grosso, Maranhão e Tocantins esse indicador encontra-se entre 5 a 10 por 10.000 hab. Esse padrão de redução da carga com persistência de desigualdade também é observado quando se analisa o coeficiente de detecção da doença. Entre 2002 e 2011, esse indicador apresentou, para o país, uma redução de $45,2 \%$, de 28,3 por 100.000 hab. para 17,65. Os maiores coeficientes de detecção foram verificados nas regiões Norte e Centro-Oeste, com 42,7 e 40,4 casos novos por 100 mil habitantes em 2011, que caracterizam hiperendemicidade. Por outro lado, as regiões Sul e Sudeste apresentam 5,0 e 7,4 casos novos por 100 mil habitantes e o Nordeste, 26,1 casos novos por 100 mil hab (BRASIL, 2013c). Em análise da distribuição espacial da endemia, Penna e col. identificaram 10 "clusters" espaciais de casos de hanseníase, em sua maioria, localizados nas regiões Norte, Nordeste e Centro-Oeste. Estes aglomerados incluíam 1.173 municípios, onde viviam 53,\% dos casos de hanseníase do país (PENNA et al, 2009).

Em 2011, o Ministério da Saúde retoma a estratégia da eliminação da hanseníase enquanto problema de saúde pública, que havia sido substituída por uma estratégia de controle, em 2007, com o lançamento do "Plano integrado de ações estratégicas de eliminação da hanseníase, filariose, esquistossomose e oncocercose como problema de saúde pública, tracoma como causa de cegueira e controle das geohelmintíases: plano de ação 2011-2015”. Nesse Plano, além de buscar uma abordagem integrada entre doenças transmissíveis relacionadas com a pobreza para as quais se dispõe de ferramentas e estratégias capazes de reduzir drasticamente sua carga, é proposta uma forte integração com a Estratégia de Saúde da Família e ações específicas dirigidas às populações mais vulneráveis (BRASIL, 2012b).

\subsection{Tuberculose}

A incidência de tuberculose aumentou no Brasil até o início da década de 1990. A partir de então, observa-se uma tendência sustentada de redução da incidência, que caiu de 51,4 por 100.000 hab. em 1990, para 36,0 em 2011, alcançando 30\% de 
redução. A taxa de mortalidade reduziu-se 22,6\% no período de 2001 a 2010, de 3.1 óbitos p/ 100.000 hab. para 2,4 p/100.000 hab. A redução obtida nas décadas recentes, principalmente nos últimos 10 anos, colocou o Brasil como o país de menor incidência entre os 22 de maior carga de tuberculose. Quando comparado aos outros países, o Brasil ocupa a $17^{a}$ posição quanto ao número de casos, entretanto está na posição $111^{a}$ em relação ao coeficiente de incidência. Esses dados geraram o reconhecimento da Organização Mundial da Saúde e das Nações Unidas de que o país atingiu a meta prevista para a tuberculose nos Objetivos de Desenvolvimento do Milênio em 2011, com quatro anos de antecipação (BRASIL, 2012c; WHO, 2011).

Apesar desse resultado positivo em escala nacional, observa-se importante desigualdade entre os estados e municípios e grupos populacionais mais vulneráveis quanto à ocorrência de tuberculose. O Amazonas $(62,6)$ e o Rio de Janeiro $(57,6)$ apresentam as maiores taxas de incidência entre as UF, enquanto as menores são as apresentadas por Goiás $(13,6)$ e Distrito Federal $(11,1)$. A tuberculose no Brasil acomete predominantemente adultos jovens do sexo masculino, com baixa escolaridade, de raça/cor não branca. Em alguns grupos populacionais, há uma forte concentração de incidência: entre a população vivendo em situação de rua, a incidência é estimada como sendo 48 a 67 vezes maior que a média nacional; entre a população privada de liberdade a incidência pode alcançar 2.000 casos por 100.000 hab.; e entre os indígenas, a incidência é quase três vezes a média nacional, atingindo 95,5 p/100.000 hab. (BRASIL, 2012c). Um importante indicador da concentração da doença entre os mais pobres é revelado pelo fato de que, em 2011, 25\% dos casos de tuberculose eram de pessoas que estavam também registradas no Cadastro Único para Programas Sociais do Governo Federal (CadÚnico), instrumento do Ministério do Desenvolvimento Social que identifica e caracteriza as famílias de baixa renda (BRASIL, 2013d).

O Brasil supera a meta global de detectar $80 \%$ dos casos estimados, tendo alcançado o percentual de 88\% de taxa de detecção para o ano de 2010, resultado para o qual pode ter contribuído a estratégia de integração com a atenção primária de saúde que, em 2001, era responsável pelo diagnóstico de 50,1\% dos casos pulmonares bacilíferos, atingindo um aumento de 11\% até 2010 quando 56,3\% do total dos casos passaram a ser aí diagnosticados. Desde 2011, o MS vem adotando novas estratégias para capacitar e garantir que as ESF realmente realizem as ações de diagnóstico e tratamento dos casos de tuberculose. Entre os anos de 2001 a 2004, o percentual de cura cresceu, mas vem se mantendo estável desde 2005, em torno de 70\% a 73\%, revelando a necessidade de expansão do tratamento diretamente supervisionado (DOTS por sua sigla em inglês), especialmente entre os grupos mais vulneráveis e melhora no sistema de registro (BRASIL, 2013d).

Se por um lado, a proporção de unidades de saúde oferecendo o tratamento diretamente observado vem aumentando, tendo atingido os $81 \%$ das unidades em 2006 (SANTOS, 2007), por outro, em análise realizada a partir dos dados da coorte de 
casos novos de 2007, observou-se que, naquele ano, apenas 43,6\% dos casos notificados foi submetida a DOTS. O DOTS vem sendo utilizado de forma seletiva pela rede de saúde, priorizando os pacientes com maior vulnerabilidade, como os com menor nível de escolaridade, institucionalizados, alcoolistas e portadores de doenças mentais (DIMECH, 2007).

A reduzida proporção de casos em crianças e adolescentes sugere que a vacina BCG vem sendo relativamente efetiva na proteção destes grupos populacionais (BRASIL, 2006b). Esta vacina é a que apresenta maiores coberturas vacinais, dentre as vacinas administradas às crianças no país (CARVALHO et al, 2009).

A padronização nacional dos esquemas terapêuticos, que vem sendo realizada há quase cinquenta anos, trouxe como resultado a baixa proporção de casos resistentes às drogas de primeira escolha, quando comparado à maioria dos demais países endêmicos. Entretanto, evidências de aumento na proporção de casos resistentes levaram, em 2009, à mudança no esquema terapêutico em uso no país, com a introdução de uma quarta droga, o etambutol (DALCOMO, 2007; BRASIL, 2009c).

A proporção de casos novos de tuberculose com sorologia reagente para o HIV tem se mantido relativamente constante nos últimos anos. Por outro lado, é crescente a testagem para o HIV entre os casos novos de tuberculose, que em 2011 alcançou o percentual de 63,0\%, um crescimento de 59\% em relação ao percentual observado em 2001, que era de 26\% (BRASIL, 2012c).

\subsection{Tracoma}

O tracoma endêmico, potencial causador de cegueira, continua a ocorrer no Brasil, de maneira focalizada em municípios com piores condições sociais, embora a detecção de casos de cegueira pela doença seja pouco frequente. Intimamente relacionado à pobreza e às condições precárias de higiene, o tracoma teria sido introduzido no Brasil pelas ondas migratórias procedentes do sul da Europa, Oriente Médio e Ásia. Ao início do século XX havia se tornado hiperendêmico em todo o país.

As primeiras medidas de controle do tracoma no Brasil foram implantadas pelo Estado de São Paulo, em 1907, mas só em 1943 o Governo Federal implantou a Campanha Nacional do Tracoma. Já a partir da década de 1950 começa-se a observar a queda nos indicadores de ocorrência da doença no Estado de São Paulo, e em meados da década de 1970 o tracoma foi considerado "erradicado" no Estado. Já em nível nacional, essa tendência não foi tão evidente. Naquela época, o programa de controle federal nunca chegou a ter uma abrangência nacional de fato, restringindo sua atuação aos chamados "bolsões tradicionais" de ocorrência da doença. Além disso, os dados divulgados pelo programa refletiam mais o desempenho físico das ações do que indicadores epidemiológicos de base populacional. 
A partir da década de oitenta, o programa nacional foi sendo desarticulado e praticamente deixou de ser executado por uma década, só sendo retomado a partir do final dos anos 90. No inquérito nacional de prevalência entre escolares residentes e municípios com baixo Índice de Desenvolvimento Humano (IDH), realizado a partir de 2002, uma prevalência de 5,1\% de tracoma ativo foi detectada. Dos 1.514 municípios incluídos na amostra nacional, 234 (15\%) apresentou prevalência acima de 10\%, nível limite para a indicação de tratamento coletivo (LOPES et al, no prelo). Inquéritos mais recentes, como o realizado em Pernambuco em 2011 e 2012, em 79.280 escolares de 22 municípios de baixo IDH, encontraram uma prevalência de 3,0\%. Nesse mesmo estado, resultados preliminares com um ano de intervenção em um município de alta prevalência, Ferreiros, demonstrou uma redução de 6,2\%, em 2011, para 1,8\%, em 2012 (PERNAMBUCO, SES, mimeo, s/d).

\section{4| Malária}

A ocorrência de malária está quase que circunscrita à Região Amazônica, de onde se originam 99\% dos casos registrados no país. Após o sucesso inicial do programa de controle da malária, chegando-se ao nível mínimo de detecção de casos no ano de 1969, com apenas 52.469 casos notificados, o número de casos voltou a crescer de forma intensa, em decorrência do processo de colonização e ocupação da Amazônia, chegando a picos com mais de 600 mil casos em 1999, 2000 e 2004. A partir de 2004 observa-se tendência sustentada de redução no número de casos. Em 2009, cerca de 330 mil casos foram confirmados, e em 2012 um pouco mais de 240 mil. A descentralização do programa ampliou o acesso ao diagnóstico e tratamento.

A utilização de esquemas terapêuticos padronizados garantiu a manutenção de baixos níveis de resistência dos parasitas ao tratamento. Em 2006, após a observação do aumento da proporção de casos pelo Plasmodium falciparum, que chegou naquele ano a 26,3\%, foi feita uma mudança no esquema terapêutico em uso, com a introdução de derivados da artemisina. A proporção de casos por P.falciparum caiu para 15\% em 2008 e 16\% em 2009. A letalidade é baixa e decrescente, mantendose inferior a $1 \%$.

A ocorrência de malária na região Amazônica é influenciada pelo processo desordenado de urbanização e ocupação, bem como aos movimentos de valorização cíclica de atividades extrativistas e de mineração, e às oscilações no grau de prioridade conferido ao problema pelos sistemas locais de saúde (TAUIL, 2010; BRASIL, 2013e).

\section{5| Doença Meningocócica}

O Brasil passou por quatro grandes epidemias de doença meningocócica durante o século XX, entre 1920 a 1926, entre 1945 e 1951(sorogrupo A), entre 1971 e 
1976 (sorogrupos A e C), e entre 1988 a 2003 (sorogrupo B) (FONSECA et al, 2004). Nos últimos anos, em torno de 3.000 casos confirmados de doença meningocócica vem sendo registrados. A maior incidência está entre os menores de um ano de idade e o maior número de casos entre 1 e 4 anos. A letalidade está em torno de 20\%. A partir de 2005 observa-se a predominância do sorogrupo C, dentre os casos com esta informação. Na última década vem aumentando a detecção de surtos de doenças meningocócica, em comunidades com precárias condições de vida, e em instituições educacionais envolvendo adolescentes e adultos jovens. A recente introdução da vacina conjugada contra o sorogrupo C provavelmente apresentará impacto em curto prazo na incidência no grupo etário de maior risco. Deve persistir a tendência de ocorrência de surtos em instituições envolvendo adolescentes e adultos jovens.

\section{6| Geohelmintíases e Protozooses Intestinais}

Apesar da tendência de redução da prevalência das helmintíases transmitidas pelo solo e das protozooses intestinais, esta permanece em níveis elevados em algumas áreas do país, variando de 1\% a mais de 70\%, em diferentes estudos (PULLAN et al, 2008; GONÇALVES et al, 2011; QUADROS et al, 2004; CARVALHO et al, 2002). A prevalência entre escolares nos municípios com baixo IDH chega a 70\% (FONSECA, et al., 2010). Até 2011, quando o Ministério da Saúde lançou o "Plano integrado de ações estratégicas de eliminação da hanseníase, filariose, esquistossomose e oncocercose como problema de saúde pública, tracoma como causa de cegueira e controle das geohelmintíases: plano de ação 2011-2015”, não existiam iniciativas de controle de abrangência nacional e o país não adotava estratégias de tratamento coletivo em áreas de altas prevalências, recomendando o diagnóstico e tratamento individualizado, absolutamente incapazes de produzir impactos rápidos e relevantes na carga dessa doença (BRASIL, 2012b). Em decorrência dessa mudança de estratégia, foi realizada em março de 2013 a primeira campanha voltada à massificação do tratamento e prevenção com o albendazol entre estudantes de escolas públicas de municípios com maior vulnerabilidade social. Embora sejam doenças que respondem à melhoria das condições de saneamento básico, como a ampliação de cobertura das redes de abastecimento de água e esgotamento sanitário (MASCARINI-SERRA, 2010), essas doenças continuam a afetar, com elevada prevalência, as populações das zonas rurais, das pequenas cidades do interior, e as populações urbanas marginalizadas. A manutenção dessas iniciativas de abrangência nacional com estratégias mais eficazes deverá apresentar impacto na redução da prevalência das parasitoses intestinais em médio prazo. 


\section{7| Cisticercose}

A infecção pelas formas larvárias da Taenia solium continua a ser um importante problema de saúde pública no país. Não existe um programa de controle em nível nacional, e apenas quatro estados tem programas estaduais (MS, MG, PR e SC). Não há dados estatísticos de abrangência nacional. Em uma extensa revisão bibliográfica publicada em 2003, abrangendo o período entre 1915 e 2002, os autores relataram a presença de sinais de cisticercose em 1,5\% das necropsias e 3\% dos pacientes em estudos clínicos da doença (AGAPEJEV, 2003).

\section{8| Toxoplasmose}

Zoonose de felinos, transmitida ao homem pela ingestão de alimentos cárneos contendo cistos, ou água e/ou alimento contaminados com os oocistos do Toxoplasma gondii, a toxoplasmose é endêmica no Brasil. A prevalência de marcadores sorológicos na população varia de 50 a 80\% (KOMPALIC-CRISTO et al, 2005). Embora o exame sorológico para detecção de anticorpos contra o agente etiológico e o tratamento dos casos considerados como "infecção recente" façam parte da rotina da atenção pré-natal no país, não existe um programa de controle da toxoplasmose de abrangência nacional. O controle da toxoplasmose envolve a saúde pública veterinária, e a área do controle sanitário dos alimentos. Uma dificuldade adicional ao controle dos alimentos contaminados é a inexistência de tecnologia, com comprovação de sua validade, para a detecção dos alimentos contaminados. Com a ampliação, na última década, da capacidade de detecção e investigação de surtos no Brasil, grandes surtos de toxoplasmose aguda vêm sendo investigados no país, tanto relacionados à contaminação de água para consumo humano com oocistos do Toxoplasma gondii quanto pela ingestão de alimentos cárneos contendo cistos do agente etiológico (MOURA et al, 2006; RENOINER et al, 2007).

\section{9| Febre Tifoide}

O número de casos confirmados de febre tifóide apresentou grande variabilidade na última década, de um mínimo de 9 casos em 1999, ao máximo de 869 em 2003, relacionada com a ocorrência de surtos em determinados anos. A grande maioria dos casos confirmados estava nas regiões Norte e Nordeste, por sua relação com precárias condições sanitárias. O quadro clínico inespecífico e as dificuldades na confirmação laboratorial podem contribuir para a subnotificação da doença (BRASIL, 2011a). 


\subsection{0 | Sífilis e Sífilis Congênita}

A sífilis é uma doença sexualmente transmissível com características endêmicas no Brasil. Em 1995, foi lançado pela Organização Pan-americana da Saúde o Plano de Eliminação da Sífilis Congênita nas Américas (ZACARÍAS, 2005). Desde 1998 a sífilis congênita faz parte da lista de doenças de notificação compulsória no país. Em 2005, a sífilis em gestantes também passou a ser de notificação compulsória, e por fim, em 2010, todos os casos de sífilis adquirida foram incluídos no elenco de doenças de notificação compulsória. Em 2005, estimou-se uma prevalência de sífilis em parturientes de 1,6\%, correspondendo a cerca de 50 mil casos, e cerca de 12 mil casos de sífilis congênita. O número de casos notificados em gestantes vem aumentando desde 2005, tendo chegado a quase 9 mil casos em 2009, refletindo, em parte, o aumento de cobertura da realização da triagem durante o pré-natal. Já o número anual de casos de sífilis congênita manteve-se em torno de 5 mil durante a última década (BRASIL, 2010c). A partir de 2011, a eliminação da sífilis congênita enquanto problema de saúde pública (incidência menor que p/1.000 nascidos vivos) passa a integrar um dos programas prioritários do Ministério da Saúde, o Rede Cegonha, assumindo uma condição prioritária que pode produzir uma rápida redução nos próximos anos (BRASIL, 2013f).

\subsection{1 | Outras Doenças Sexualmente Transmissíveis}

As doenças sexualmente transmissíveis que cursam com corrimento vaginal ou uretral, com ulcerações genitais e com verrugas genitais ocorrem de forma endêmica no Brasil. A ausência de um sistema de coleta de dados de base nacional sobre sua ocorrência dificulta uma estimativa das dimensões do problema. Estudo realizado pelo Ministério da Saúde em seis capitais de estados brasileiros, envolvendo uma amostra de gestantes e de trabalhadores industriais revelou uma prevalência de 25,2\% de candidíase e 33,4\% de HPV 16/18 entre as gestantes; de 1,5\% e 0,9\% de gonorreia; de $9,3 \%$ e 3,5\% de Chlamydia trachomatis; e $22,7 \%$ e $12,5 \%$ de HSV2; entre gestantes e trabalhadores respectivamente. Entre pacientes de clínicas de DST, as prevalências foram: 0,4\% e 2,4\% de gonorreia; $39 \%$ e 18,3\% de HSV2; $2,2 \%$ e $4,5 \%$ de Chalmydia trachomatis, e $36,2 \%$ e 3,2\% de HPV 16/18, entre mulheres e homens, respectivamente (BRASIL, 2006c).

O lançamento das vacinas contra as infecções pelo papilomavírus humano fez aumentar o interesse por estudos de sua distribuição no país. Em uma amostra de mulheres, da clientela de um serviço de atenção primária em São Paulo, verificou-se uma prevalência de 20,2\% de HPV de alto risco oncogênico (LIPPMANN et al, 2010). Em estudo com mulheres com citologia vaginal alterada, realizado no Rio de Janeiro, foi possível identificar o HPV em 44\% delas (OLIVEIRA-SILVA et al, 2011). Em 
revisão sistemática, publicada em 2010, sobre a prevalência de HPV cervical no Brasil, as autoras selecionaram 14 estudos de interesse. A prevalência total variou entre 13,7\% e 54,3\% (AYRES \& SILVA, 2010). Um dos poucos estudos realizados em uma amostra de homens com práticas heterossexuais, em São Paulo, a prevalência de HPV (todos os tipos) foi de 10,9\%, sendo de 4,9\% dos tipos oncogênicos (NYITRAY et al, 2010).

\subsection{2 | Peste}

Apesar de existirem 20 focos naturais de peste no país, a maioria deles na região Nordeste, a doença apresenta atualmente uma ocorrência esporádica, sem impacto para a saúde pública. Há também focos nos estados do RJ e MG. No período 1983 a 2009 foram notificados 490 casos no Brasil, a maioria deles nos estados da BA (61,8\%), CE (25,7\%) e PB (11\%). Apesar dessa pequena incidência, a manutenção da circulação do agente etiológico entre roedores silvestres faz com que persista o risco de ocorrência de casos humanos, sendo necessária a manutenção das ações de vigilância da doença (BRASIL, 2010d).

\subsection{3 | Varicela}

Doença prevenível por vacina, a sua transmissão permanece endêmica no Brasil, pois a vacina vem sendo utilizada de forma restrita pelo PNI. A vacina era disponibilizada pela rede de Centros de Referência de Imunobiológicos Especiais (CRIE) apenas para determinados grupos de portadores de doenças crônicas (BRASIL, 2006d), e para controle de surtos em ambientes hospitalares e em creches, estando prevista para passar a integrar o calendário do PNI a partir do segundo semestre de 2013, o que deverá resultar em progressiva redução da incidência. Como não é doença de notificação compulsória para casos individualizados, a avaliação sobre a carga da varicela pode ser melhor percebida quando se analisa o número de internações a ela relacionadas no SUS, que apresentou uma média anual de 3.662, no período de 1998 a 2007, e o número de óbitos, que variou de 8 (em 2002) a 44 (em 2006) (BRASIL, 2013g).

\subsection{4 | Micoses Sistêmicas}

A histoplasmose, a paracoccidioidomicose e a cromoblastomicose ocorrem de forma endêmica no Brasil (MOREIRA, 2008). A sua incidência, distribuição e possível impacto em saúde pública não estão completamente estabelecidos no país. Alguns estudos revelaram alta prevalência de marcadores de infecção pregressa pelo Paracoccidioides braziliensis (FORNAJEIRO et al, 2005; KALMAR et al, 2004). Em algumas regiões do país, notadamente na fronteira agrícola, em estados das regiões Norte e Centro-Oeste, a paracoccidioidomicose vem sendo considerada uma doença emergente 
(BRASIL, 2010e). Há relatos de ocorrência da cromoblastomicose nas regiões Norte, Nordeste e Sul, com destaque para algumas regiões do estado de Rondônia.

\subsection{5 | Hidatidose}

Zoonose parasitária, cujo agente etiológico é o Equinococcus granulosus. No Brasil, é considerada endêmica em certas áreas do estado do Rio Grande do Sul, porém existem evidências de ocorrência em outras áreas do país. No estado do RS, o seu ciclo envolve, em geral, o ser humano, cães e ovinos. A informação sobre a ocorrência de hidatidose ainda é escassa e fragmentada. No período de 1981 a 1999 foram identificados no Rio Grande do Sul, 716 casos, com uma letalidade de 10\% (FAO, 2007). Entre 1995 e 2002, foram registradas mais de 8.000 internações hospitalares por hidatidose na rede do SUS. Existe o registro da doença em todas as regiões do país. Cerca de 50\% das internações hospitalares ocorreram na região Nordeste (OPAS, 2006).

\section{DOENÇAS EMERGENTES E REEMERGENTES}

Nesse grupo de doenças incluem-se a dengue, o HIV/Aids, a cólera, as leishmanioses, as doenças transmitidas por alimentos, as hantaviroses, a febre maculosa, e as infecções hospitalares.

\section{1 | Cólera}

Iniciada em 1961, a sétima pandemia de cólera chegou à América do Sul pela costa peruana, no início de 1991. Encontrando condições favoráveis a sua disseminação, a doença rapidamente chegou a quase todos os países do subcontinente. No Brasil, os primeiros casos foram detectados em agosto do mesmo ano, na região do Alto Solimões, estado do Amazonas, na tríplice fronteira entre o Brasil, Peru e Colômbia. Seguiu-se uma rápida disseminação da doença, principalmente nos estados das regiões Norte e Nordeste, e com reduzidas dimensões nas regiões Sudeste e CentroOeste. O pico da epidemia no Brasil foi em 1993, quando foram confirmados mais de 60 mil casos e 670 óbitos. Os estados mais atingidos foram o Ceará e Pernambuco (BARBOSA DA SILVA JR, 2009). Em 1999, ocorreu um surto na região Sul, única região até então poupada pela epidemia, com cerca de 500 casos na cidade portuária de Paranaguá, estado do Paraná, relacionado ao consumo de frutos do mar, e que foi, rapidamente controlada (PASSOS, 1999). No Nordeste, o número de casos reduziu-se gradativamente, e em 2001 registraram-se os últimos casos da doença. Em 2004 e 2005 ocorreram surtos, de pequenas proporções, em um município do interior do estado de Pernambuco. 
Em outubro de 2010, a cólera ressurgiu na Região das Américas produzindo uma importante epidemia no Haiti, que naquele mesmo ano havia sofrido terremoto de graves consequências. Apesar da redução progressiva na letalidade e na incidência, a transmissão ainda persiste naquele país e, pelas características da cólera e da situação sanitária e social do Haiti, espera-se que continue durante alguns anos (CDC, 2013). Essa reemergência não produziu transmissão em outros países da região, além da República Dominicana, que é vizinha ao Haiti, entretanto serve de alerta para a necessidade de manutenção das ações de vigilância sobre as doenças diarreicas.

\subsection{Dengue}

A dengue foi detectada no Brasil, pela primeira vez em época recente, em um surto na cidade de Boa Vista, capital do então território federal de Roraima, entre 1981 e 1982, durante a qual foram isolados os vírus DENV1 e DENV4 (OSANAI et al, 1983). A situação de relativo isolamento daquele território do restante do país, à época, contribuiu para que não tenha ocorrido a disseminação para outras regiões do Brasil.

Pouco tempo depois, a dengue emergiu no Rio de Janeiro, em 1986, naquela que posteriormente se configuraria enquanto a primeira onda epidêmica no país. A epidemia de 1986-87, cujo agente etiológico foi o DENV1, teve o seu epicentro na Região Metropolitana do Rio de Janeiro, e atingiu também algumas capitais nordestinas, como Fortaleza, Maceió e Recife. Entre 1990 e 1991 observa-se a segunda onda epidêmica no país, pela introdução do DEN2, outra vez no Rio de Janeiro, com disseminação para as capitais nordestinas e para outros estados das regiões sudeste e centro-oeste. A partir de 1994 a incidência volta a crescer, atingindo o pico em 1998, e configurando a terceira onda epidêmica no Brasil, com a transmissão do DENV1 e do DENV2 (BRASIL, 2008a).

Em 2000 foi detectada a introdução do DENV3. Nesse mesmo ano o número de casos volta a crescer, atingindo um pico dois anos depois, na quarta onda epidêmica, que se caracteriza por um volume de casos muito maior que nas ondas anteriores, pela ampliação geográfica da transmissão, pela redução da faixa etária e aumento da ocorrência de casos graves e fatais (BRASIL, 2013h; TEIXEIRA et al, 2005).

Observou-se um novo aumento no número de casos a partir de 2005, configurando-se no período 2005-2008 a quinta onda epidêmica no país. Em 2010, observou-se um novo pico epidêmico, o maior até o momento, com o registro de cerca de 1 milhão de casos, e a confirmação da circulação do DENV 4. Atualmente, verifica-se a circulação simultânea dos quatro sorotipos (BRASIL, 2013h).

A dengue tornou-se endêmica no Brasil e cursa com picos sazonais e ciclos epidêmicos. A transmissão, embora mais intensa no verão, pode ocorrer durante todo o ano, em especial nas regiões de clima quente e úmido. A configuração dos picos sazonais é determinada pela ocorrência de epidemias localizadas e periódicas, que 
atingem diferentes regiões geográficas, estados e cidades, podendo voltar a ocorrer em uma mesma população quando se introduz um novo sorotipo ou depois de um período de tempo longo o suficiente para produzir um agrupamento importante de suscetíveis pelo acúmulo das coortes dos nascidos após a primeira epidemia.

As epidemias de dengue em nível nacional representam a somatória de múltiplas epidemias localizadas, com maiores ou menores dimensões, determinadas pela proporção de suscetíveis na população, pelo sorotipo circulante, pelo grau de densidade vetorial, pela efetividade das intervenções de controle, e por outros fatores. De maneira geral, pode-se afirmar que, no ciclo epidêmico de 2010, intensificaram-se as tendências já observadas anteriormente, de ampliação da área geográfica de transmissão, como o envolvimento de médias e pequenas cidades, redução da faixa etária de ocorrência dos casos, aumento da gravidade e da letalidade. O último pico epidêmico, no verão 2009 2010 representou um recorde no número de casos notificados e de óbitos.

Inquéritos sorológicos realizados após ondas epidêmicas e mesmo após períodos considerados não epidêmicos apontam para uma ocorrência da infecção muito superior àquela indicada pelas notificações, porque parte dos casos é de assintomáticos ou oligossintomáticos. Teixeira e col. demonstraram uma prevalência de 68\% de marcadores sorológicos de dengue em Salvador, após a epidemia de 1998, e uma incidência de 70\% no ano seguinte, ano considerado não epidêmico e com um pequeno número de casos notificados na capital baiana (TEIXEIRA et al, 2003). Outros inquéritos sorológicos realizados em diferentes cidades do país também demonstraram alta prevalência de marcadores sorológicos de infecção pregressa: 44\% em Fortaleza CE, em 1994; 41,5\% nos municípios da ilha de São Luís, no Maranhão em 1996; 14,8\% em Campinas - SP em 1998; 29,5\% de Goiânia - GO, em 2002; e 61\% no Rio de Janeiro em 2007 (VASCONCELOS et al, 1998; VASCONCELOS et al, 1999; SIQUEIRA et al, 2004; TEIXEIRA et al, 2002; LIMA et al, 2007; HONÓRIO et al. 2009). No estudo do Rio de Janeiro a proporção de resultados de sorologias IgM positivos aumentou de 2,7\% para 9,3\% na segunda coleta, realizada entre três e cinco meses após a primeira. À exceção dos estudos de Teixeira e col. e Honório e col. não foram encontrados na literatura outros estudos que aferissem a incidência da infecção pelos vírus da dengue na população brasileira (LIMA et al, 2007; HONÓRIO et al. 2009).

Em que pese um investimento considerável de recursos no programa de controle, estimado em cerca de 900 milhões de reais ao ano (BRASIL, 2013a), a dengue parece seguir seu curso "natural", sem que se verifique impacto importante das ações realizadas para o controle do vetor em relação a sua capacidade de evitar, de maneira sustentada, a ocorrência de epidemias. Parte deste aparente fracasso pode ser creditada às dificuldades inerentes ao próprio processo de determinação da emergência da dengue enquanto epidemia em escala mundial. A expansão da dengue, a partir dos anos setenta, coincide com a intensificação da migração do campo para as cidades, especialmente no mundo subdesenvolvido, com a formação de megalópoles, sem uma 
adequada infraestrutura de saneamento básico, habitação, coleta de resíduos sólidos e drenagem de águas pluviais. Houve importantes mudanças socio-econômicasculturais nesse período, como a introdução crescente de plásticos e descartáveis nos produtos do dia a dia, o que acarreta inúmeras possibilidades de produção de criadouros do mosquito, no lixo familiar diário. A massificação do transporte aéreo, além de ampliar o volume de passageiros, reduziu o tempo de viagens nacionais e internacionais. O incremento do comércio internacional ampliou o volume de cargas sendo transportadas entre os países, assim como o número de veículos para transportá-las. As mudanças climáticas, com a elevação de temperaturas em grande parte do globo, podem se constituir em um fator adicional a facilitar a sobrevivência do inseto vetor do vírus da dengue. Outra parte está relacionada com a diversidade que se observa na capacidade técnica, administrativo-gerencial e de compromisso com as ações de prevenção por parte dos municípios brasileiros, responsáveis pela execução direta das atividades de controle.

Esse cenário complexo parece apontar claramente para a imperiosa necessidade de desenvolvimento de novas tecnologias, ferramentas e estratégias capazes de promover um controle mais efetivo da população do mosquito transmissor. Algumas dessas inovações, como a implantação de ferramentas de vigilância entomológica mais sensíveis, como o Levantamento Rápido do Índice de Infestação do A. aegypti (LIRAa) já se encontram em processo de implantação, com o objetivo de aumentar a capacidade de predição do risco de epidemias. Outras, como os estudos para a identificação de população alvo a ser vacinada, o desenvolvimento de vacinas contra a dengue e a infecção do A. aegypti com a bactéria Wolbachia têm sido apoiadas pelo Ministério da Saúde, mas ainda levarão alguns anos até poderem ser utilizadas no controle da doença (BRASIL, 2013a).

A partir de 2011 foram introduzidas mudanças importantes na resposta às epidemias de dengue, antes quase exclusivamente focadas no controle vetorial, passando-se a adotar uma maior integração com os serviços assistenciais para implantação de novo protocolo visando à detecção precoce de sinais e sintomas de agravamento e a adoção oportuna de medidas de tratamento mais adequadas. Essas medidas, conjuntamente com a elaboração e implantação de planos de contingência e uma melhor organização de fluxos no atendimento aos casos de dengue produziram uma importante redução nos casos graves e óbitos, mesmo na condição desfavorável produzida pela disseminação de um novo sorotipo, o DENV 4. Em 2010 foram registrados 17.474 casos graves e 656 óbitos, enquanto em 2012 esses números foram de 3.965 e 283, reduções de 77,3 e 56,8\%, respectivamente (BRASIL, 2013a). 


\section{3 | HIV/AIDS}

Os primeiros casos de Aids no Brasil ocorreram quase que simultaneamente à detecção da nova doença nos EUA e Europa Ocidental. Durante a primeira década da epidemia, a incidência de Aids manteve-se em um patamar relativamente baixo. A maioria dos casos concentrava-se nas grandes metrópoles, e os grupos mais atingidos eram os homens que fazem sexo com homens (HSH) e os usuários de drogas injetáveis. Na década de 1990 a incidência aumentou, chegando ao final da década a cerca de 30 mil casos novos anuais. Quando se analisa a série histórica dos casos registrados de Aids, observa-se em 2002 um aumento brusco na incidência, de 31.649 casos no ano anterior para 37.902, o que não é esperado pelo comportamento da doença, provavelmente relacionado com melhoras no sistema de registro de casos, que utiliza sistemas complementares ao SINAN, como o SIM, SISCEL e o SICLOM. Entre 2003 e 2009, o número de casos novos ficou entre um mínimo de 34.614 em 2006, e o máximo de 38.538 em 2009 (BRASIL, 2010c). Para contextualizar a análise, é importante destacar que pelo longo período de incubação, os casos novos registrados de doença Aids em um determinado ano, refletem as características e dinâmica de transmissão do HIV que ocorriam 10 ou mais anos antes do surgimento da doença.

A prevalência da infecção pelo HIV na população brasileira adulta é baixa, quando comparada ao panorama global. Estimativas recentes do Ministério da Saúde e do Programa Conjunto das Nações Unidas sobre HIV/Aids (UNAIDS), em 2010, calculam que cerca de $0,4 \%$ da população brasileira adulta de 15 a 49 anos estariam infectados pelo HIV, correspondendo a aproximadamente 530 mil pessoas, quando as estimativas anteriores colocavam esse percentual em 0,6\%. Essa diferença é fundamentalmente relacionada com aperfeiçoamentos da metodologia e maior consistência na série histórica utilizada para as projeções. Entre os homens a estimativa é de 0,52\%, enquanto para as mulheres é de 0,31\%, diferença que expressa o risco desigual de contrair a infecção que existe entre os dois sexos (BRASIL, 2013i; ONU, 2013).

Entretanto, o Brasil apresenta uma situação de epidemias concentradas, pois no interior dessa prevalência geral reduzida, encontram-se taxas elevadas em determinadas populações mais vulneráveis à transmissão do HIV, como jovens HSH, que podem chegar aos 12\%. A maior vulnerabilidade dessa população pode ser observada também quando se analisa a categoria de exposição entre os casos de Aids registrados em jovens de 15 a 24 anos, pois HSH representavam 36,6\% dos casos em 2002, percentual que se eleva para 53,6\% em 2011 (BRASIL, 2013i e 2012d).

As diferentes dinâmicas de transmissão também se revelam nas desigualdades regionais observadas pela taxa de incidência da doença. Na região Sudeste, a taxa de incidência vem apresentando, de maneira consistente, tendência de redução, tendo diminuído de 22,7 por 100.000 habitantes, em 2000, para 12,1 em 
2011. Nas regiões Sul e Centro-Oeste, há tendência de estabilização ou muito discreta redução, com valores, para os anos de 2000 e 2011, de 24,3/100.000 hab. e 22,3/100.000 hab. e 12,8/100.000 hab. e 11,4/100.000 hab., respectivamente. No Nordeste, nesse mesmo período, observa-se discreto aumento, de 6,2/100.000 hab. para 8,7/100.000 hab., enquanto na região Norte, há um nítido aumento da incidência, com a taxa subindo de 6,1/100.000 hab. para 10,0/100.000 hab. (BRASIL, 2013i e 2012d).

Apesar de haver uma maior dispersão em todos os municípios, as maiores incidências são encontradas em grandes cidades. Em 2011, a taxa entre os municípios com mais de 500.000 habitantes era três vezes maior que a encontrada nos municípios com menos de 50.000 habitantes (9,8/100.000 hab.). Entre as capitais, Porto Alegre, com 95,3/100.000 hab. apresenta a maior taxa de incidência, quase cinco vezes maior que a média nacional (20,2/100.000hab.), seguida de Florianópolis (71.6/100.000 hab.) e Manaus (48,6/100.000 hab.) (BRASIL, $2013 i$ e 2012d).

A taxa de mortalidade por Aids aumentou até 1995, passando a apresentar, a partir de então, tendência de decréscimo, ainda que com variações regionais importantes, pois no Norte e Nordeste a tendência é de crescimento.Em 2000, a taxa de mortalidade era de 6,3/100.000 hab., tendo se reduzido para 5,6/100.000 hab. em 2011 (BRASIL, 2013i e 2012d).

Nos anos recentes, como resultado de esforços para massificar a realização de testagem para o HIV, tem havido um aumento no percentual de pacientes portadores do HIV que são identificados mais precocemente. Em 2006, 32,0\% dos casos de Aids apresentavam CD4 acima de 500 células $/ \mathrm{mm}^{3}$, percentual que se elevou para 36,7\% em 2011. Ao mesmo tempo, tem se reduzido o percentual de casos com diagnóstico tardio, que era de 31,2\%, em 2006, e, em 2011, é de 29,2\% em 2011 (BRASIL, $2013 i$ e 2012d).

O diagnóstico tardio e o abandono do tratamento são os principais fatores preditores do óbito por Aids (VERAS et al, 2011). A partir da introdução da terapêutica antirretroviral (TARV) de alto impacto, em 1996, a sobrevida dos pacientes aumentou, de 16 meses (coorte de 1995), para 58 meses (coorte de 1996), e para 108 meses (coorte de 1998/1999) (MARINS JRP et al, 2003; GUIBU et al, 2011). Outro dado que revela o sucesso da política de universalização do TARV e da introdução progressiva de novos e mais eficientes medicamento é a redução na circulação do vírus após seis meses de tratamento. 63,8\% dos pacientes em TARV apresentavam carga viral indetectável (carga viral abaixo de 50 cópias) em 2006, percentual que aumentou para 72,4\% em 2010 (BRASIL, 2013 i e 2012d).

A proporção de casos no sexo feminino aumentou, e a razão de casos entre os sexos que era de 5,5:1, em 1990, decresceu para 1,6:1, em 2001, permanecendo estabilizada nesse patamar até 2010, quando passa a apresentar uma discreta elevação, atingindo 1,9:1 em 2011. Para o sexo masculino, a proporção de casos classificados na categoria de exposição homo/bissexual caiu de 47\% em 1988 para 28,5 em 2000, tendo 
a partir de então apresentado discreta tendência de aumento, atingindo os 32,2\%, em 2012. Neste ano, cerca de $20 \%$ dos casos do sexo masculino apresentavam categoria de exposição ignorada. No mesmo período a categoria de exposição heterossexual aumenta, atingindo 86,8\% dos casos no sexo feminino, e 43,5\% no sexo masculino, em 2012. A transmissão sanguínea e entre hemofílicos foi praticamente eliminada do país, e a categoria de exposição de usuário de droga injetável caiu de 17,3\% para 4\%, entre 2000 e 2012, no sexo masculino, e de 6,1\% para 2,3\%, no sexo feminino, nesse mesmo período. Em 2011 foram notificados 469 casos de Aids por transmissão vertical, entretanto, apenas 93 eram em menores de um ano, demonstrando que essa forma de transmissão encontra-se em processo de eliminação, o que poderá ser acelerado com a recente incorporação tecnológica dos testes rápidos para detecção do HIV durante a gestação. Essa nova estratégia pode garantir a cobertura com testes em áreas de difícil acesso e populações com maior vulnerabilidade social, contribuindo para atingir a cobertura universal de testagem no pré-natal, que já vem se ampliando, tendo crescido de 60\% em 2006 para 80\% em 2010 (BRASIL, 2013i e 2012d).

\section{4 | Leishmanioses}

Zoonoses de transmissão vetorial, as duas formas de leishmaniose ocorrem de forma endêmica no Brasil, a leishmaniose tegumentar americana (LTA), cujos agentes etiológicos no país são a Leishmania amazonensis, a Leishmania guyanensis e a Leishmania braziliensis; e a leishmaniose visceral, cujo agente etiológico é a Leishmania chagasi. Doenças que no passado eram classificadas como endemias rurais, a partir de meados da década de oitenta assumem características que permitem classificá-las enquanto doenças reemergentes: grande aumento em sua incidência, e ampliação da área de transmissão, para regiões anteriormente consideradas indenes. Considera-se que a transmissão de LTA ocorre hoje em duas situações distintas: a silvestre, que ocorre em regiões de mata primária, tendo como reservatórios animais silvestres; e a rural/periurbana, que ocorre em regiões de colonização e em áreas periurbanas, nas quais existe a suspeita de que roedores, cães e equinos desempenhem o papel de reservatório. A transmissão da LTA hoje ocorre em todos os 27 estados do país. 0 número médio anual de casos notificados na última década está em torno de 26.000. Observam-se ciclos de transmissão, com picos a cada cinco anos. A maioria dos casos são homens adultos. A maior parte dos casos concentra-se nas regiões Norte, Nordeste e Centro-Oeste. Foram identificados 24 circuitos de transmissão da LTA no Brasil, que respondem por cerca de $75 \%$ do total de casos, sendo aqueles de transmissão mais intensa os circuitos que envolvem os estados do AC, PA, MA, MT, RO, TO e AM (BRASIL, 2007).

O número de casos de leishmaniose visceral também apresentou aumento até meados da década de 2000. Nos últimos anos o número médio anual de casos está em torno de 3.600. A letalidade está em torno de 6\%. A doença hoje é detectada em 
21 estados, nas cinco grandes regiões. A partir da década de oitenta a doença saiu dos antigos focos, localizados majoritariamente nas zonas rurais do Nordeste, e atingiu cidades de médio e grande porte, não apenas no Nordeste, como também no Norte, Centro-Oeste e Sudeste. A proporção de casos do Nordeste caiu de 83\% em 2000, para 47,5\% em 2009, já a proporção das outras três regiões somadas aumentou de 17\% para 44\% (BRASIL, 2006e; WERNECK et al, 2007).

Alguns estudos têm indicado que as tradicionais medidas de controle têm apresentado limitada efetividade na redução da transmissão da doença, o que exige esforços para desenvolvimento de estratégias e ferramentas mais eficazes (TEIXEIRA et al, 2002; LIMA et al, 2007). O Ministério da Saúde tem apoiado estudos sobre algumas dessas novas intervenções, como coleiras impregnadas com inseticidas e vacinas para aumentar a eficácia do controle, além de modificações no tratamento com o objetivo de reduzir a letalidade da doença (COSTA, 2011; BRASIL, 2013j).

\section{5 | Febre Amarela}

Os últimos casos de febre amarela em seu ciclo urbano no Brasil ocorreram em 1942. Em um período de mais de 50 anos, até o final da década de 1990, a transmissão da doença, em seu ciclo silvestre, restringiu-se às regiões Norte e CentroOeste, além de uma faixa limítrofe a essas regiões, nos estados do MA, MG, SP e PR. A área geográfica de recomendação da vacinação seguia os mesmos limites. A partir do ano 2000, com a ocorrência de surtos em GO e casos isolados no DF, configurouse um período de intensificação da circulação viral entre os primatas não humanos, e expansão da área de transmissão, para além dos limites das áreas anteriormente consideradas como endêmicas e de transição. Em 2003 registraram-se surtos em MG, e, no período 2007 - 2009, casos isolados e surtos nos estados de SP, PR e RS (KEW et al, 2005; FIGUEIREDO, 2006). Em 2008, observou-se a ocorrência de casos nas províncias argentinas que fazem fronteira com o RS, e um surto, com transmissão urbana, na periferia de Asunción, Paraguai.

Em resposta, a área de recomendação da vacinação foi ampliada, e agora inclui, além das regiões tradicionalmente consideradas endêmicas, todo o território dos estados do MA e MG, o sudoeste do PI, o oeste da BA, as regiões oeste e central do estado de SP, o oeste do PR, além de quase todo o território do RS. Recentemente tem sido procurado dar mais ênfase à necessidade de vacinação dos grupos que têm contato com áreas silvestres em decorrência de atividades de lazer ou de trabalho.

Em 1998 o Programa Nacional de Imunizações havia desencadeado o projeto de vacinação universal da população brasileira, pois se discutia a possibilidade de reemergência do ciclo urbano de transmissão, uma vez que a maioria das grandes cidades brasileiras estava infestada pelo Aedes aegypti. Entre 1998 e 2000, mais de 30 
milhões de pessoas foram vacinadas. Durante as campanhas de vacinação, identificouse pela primeira vez no mundo um grave evento adverso à vacina: a chamada "doença viscerotrópica" pelo vírus vacinal, ou seja, a febre amarela induzida pela vacina (VASCONCELOS et al, 2001). Desde então, mais de 60 casos foram identificados, em vários países do mundo, e a indicação da vacinação em massa passou a ser feita com maior cautela. A vacina contra febre amarela vem sendo utilizada no esquema básico de vacinação da criança em toda a área na qual existe a recomendação de vacinação. Observou-se em 2007 uma cobertura vacinal de 91\% nas quinze capitais de estados onde a vacina é utilizada universalmente (VERAS et al, 2010). Nos dois últimos anos não houve registro de casos de FA no país (BRASIL, 2013k).

\section{6| Hepatite C}

O vírus da hepatite $C$ foi identificado em 1989. Só então se tornou possível a realização do diagnóstico sorológico. A partir de 1993 o teste sorológico passou a ser obrigatório na triagem de doadores de sangue no Brasil. Em 2003 o SUS passou a oferecer o tratamento gratuito da doença.

O número de casos notificados vem se mantendo entre 17 e 20 mil casos anuais, desde 2005 (BRASIL, 2010f). Entretanto, a prevalência estimada pelo inquérito sorológico em amostra representativa da população das capitais dos estados e Distrito Federal foi de 1,39\% na faixa entre 10 e 69 anos de idade, variando entre $0,68 \%$ nas capitais do Nordeste e 2,1\% naquelas de região Norte (XIMENES et al, 2008). Podem existir, portanto, até cerca de 2,4 milhões de portadores da infecção na população de adolescentes e adultos do país. Apenas uma pequena proporção deles vem sendo diagnosticada e recebendo acompanhamento clínico, a cada ano. Embora uma das principais formas de transmissão tenha sido controlada (a transmissão por transfusão de sangue e derivados, e por transplantes de órgãos e tecidos), o grande número de portadores não diagnosticados pode manter a transmissão, compartilhando o uso de objetos e instrumentos perfuro-cortantes não esterilizados, bem como por outros modos de transmissão de menor eficiência, como a transmissão sexual.

Em 2012 o Ministério da Saúde decidiu incluir uma nova classe de medicamentos, os inibidores de protease, recentemente aprovados para utilização no tratamento de certas formas graves de doença hepática crônica associada à hepatite C. Além disso, tem sido promovida como uma estratégia central para a detecção precoce dos casos a intensificação da testagem, principalmente entre pessoas com idade acima de 40 anos, que podem ter se infectado em décadas passadas, quando a transmissão sanguínea ainda ocorria com muito mais frequência do que nos dias atuais (BRASIL, 20131). 


\section{7 | Doenças Transmitidas por Alimentos}

As doenças transmitidas por alimentos (DTA) são responsáveis por elevada carga de morbidade em todo o mundo. Com a intensificação do comércio de alimentos e a rapidez em seu transporte, potencializou-se o risco de ocorrência de surtos, muitas vezes atingindo amplas regiões geográficas, e implicando em grandes perdas econômicas. Estima-se a ocorrência de 48 milhões de casos anuais de DTA nos EUA, ocasionando 128 mil internações hospitalares e 3 mil óbitos (CDC, 2011).

Trata-se de um problema complexo, que envolve uma infinidade de agentes infecciosos, e quadros clínicos que nem sempre se restringem ao trato digestivo. A título de exemplo, doenças tratadas em outras seções deste capítulo, como a febre tifoide, a doença de Chagas aguda, a toxoplasmose, a cisticercose, e o cólera, podem ser de transmissão alimentar. Por vezes, os agentes das DTA não são infecciosos, e sim tóxicos.

No Brasil, a vigilância epidemiológica das DTA começou a ser implantada em 1999. O seu desempenho é heterogêneo entre os estados, havendo inclusive aqueles que nunca identificaram surtos deste grupo de doenças. No período de 1999 a 2009, um total de 6.672 surtos, envolvendo 128.954 pessoas e 82 óbitos, foi notificado no país. Em apenas 52,6\% destes foi identificado o agente etiológico. Dentre os que tiveram a identificação do agente, as bactérias do gênero Salmonella representaram 46,5\% (FIGUEIREDO, 2006; BRASIL, 2005b). Merece destaque, como exemplo da importância da vigilância sobre esse grupo de doenças, a identificação de surtos de botulismo (BRASIL, 2002a e 2010g), de toxoplasmose (PULLAN, et al, 2008), de difilobotríase pelo consumo de salmão importado do Chile (EDUARDO, 2005), de angioestrongiloidíase pelo consumo de moluscos (BRASIL, 2008b), de nefrite pós-estreptocócica pelo consumo de laticínios (BALTER et al, 2000), e de ciclosporíase (BRASIL, 2002b; SÃO PAULO, SES, 2000), dentre tantos outros.

\section{8 | Hantaviroses}

Os primeiros casos de síndrome cardiopulmonar por hantavírus foram identificados no Brasil em 1993, pouco tempo depois do reconhecimento desta nova entidade clínica, em surto no sudoeste dos EUA. Trata-se de uma zoonose de roedores silvestres da subfamília Sigmodontinae. A doença vem sendo detectada principalmente nas regiões Sudeste e Sul. Cerca de 1.200 casos foram notificados entre 1993 e 2009, a maioria no sexo masculino, em situação de risco ocupacional, como trabalhadores na agricultura, pecuária e manejo florestal (BRASIL, 2009d). Registraram-se surtos periurbanos, como o do Distrito Federal, em 2004, nos quais a exposição esteve frequentemente relacionada às atividades domésticas e de lazer (BRASIL, 2005c). Foram identificadas no país cinco variantes do vírus, cada uma delas relacionada a 
uma espécie específica de reservatório (BRASIL, 2013k). A letalidade das hantaviroses no Brasil está em torno de 40\% (BRASIL, 2009e).

\section{9| Leptospirose}

A precariedade das condições de habitação e saneamento das cidades brasileiras está relacionada à ocorrência endêmica, com eventuais picos epidêmicos, de leptospirose, em todos os estados do país. A ocupação desordenada de vales, margens de rios e córregos, e encostas, aliada a precárias condições de habitação e de saneamento, a coleta inadequada, ou inexistente, de resíduos sólidos, e a rede insuficiente ou inexistente de drenagem de águas pluviais, favorecem a proliferação de roedores e tornam a população vulnerável às inundações e à leptospirose. O país tem registrado entre 3 e 4 mil casos anuais da doença, com uma letalidade em torno de 10\% (BRASIL, 2009f).

\subsection{0 | Febre Maculosa}

Esta riquetsiose vem se apresentando de forma emergente no país, tanto em zona rural quanto em áreas urbanas. Têm sido notificados em média 100 casos anuais, com uma letalidade acima de 20\%. A maioria dos casos vem sendo notificada nos estados da região Sudeste. Mais recentemente, a doença foi detectada nos estados da região Sul e no Distrito Federal (BRASIL, 2009g e 2010h).

O aumento da ocorrência da doença tem sido relacionado, especialmente em municípios do interior de SP, ao aumento da população de capivaras (Hydrochoerus hydrochaeris), que teria acontecido após a proibição da caça deste animal. As capivaras são hospedeiros do vetor, os carrapatos do gênero Amblyomma (BRASIL, 2010h).

\subsection{1 | Influenza pandêmica}

As pandemias de influenza são fenômenos de ocorrência cíclica e não previsíveis que se relacionam à emergência de um novo subtipo viral, resultante de um shift, uma grande mutação capaz de gerar um novo vírus. Durante o século XX foram registradas três pandemias, em 1918, 1957 e 1968. Em todas elas um novo vírus, com uma nova hemaglutinina, foi o agente etiológico: Em 1918, o vírus A/H1N1, em 1957, o vírus A/H2N2, e em 1968, o vírus A/H3N2.

A emergência dos casos humanos de influenza pelo vírus aviário A/H5N1, na Tailândia em 2003, trouxe consigo a discussão sobre a preparação dos países para uma possível pandemia de influenza, e fez a Organização Mundial da Saúde (OMS) recomendar aos países que desenvolvessem planos de preparação para uma pandemia. 
Os anos de 2004 e 2005 foram marcados por uma intensa mobilização internacional, bem como na maioria dos países, no sentido da preparação para a próxima pandemia, cujo candidato a agente etiológico já havia sido identificado. Entretanto, apesar de ter ocorrido uma considerável disseminação internacional do vírus A/H5N1, saindo dos seus nichos iniciais no Sudeste da Ásia e atingindo países do Oriente Médio, África e Europa, o vírus não adquiriu a capacidade de transmissão inter-humana, e a sua esperada disseminação pandêmica não aconteceu (NORMILLE, 2008).

Porém, em abril de 2009 foram detectados nos EUA, e em seguida no México, os primeiros casos de influenza por um novo subtipo viral que viria a tornarse o agente da primeira pandemia de influenza do século XXI. Diferentemente das pandemias anteriores, o novo vírus não apresentou uma nova hemaglutinina, mas sim um novo rearranjo genético, incorporando genes de vírus suínos, aviários e humanos (H1N1 VIRUS INVESTIGATION TEAM, 2009; MORENS et al, 2009).

Em maio do mesmo ano foram identificados os primeiros casos no Brasil. O novo vírus, atualmente denominado de A/H1N1 pdm, disseminou-se rapidamente no país, particularmente no Sul, Sudeste e Centro-Oeste, e a partir de junho, repetindo o comportamento verificado globalmente, foi praticamente o único dos vírus da influenza a ser identificado pela rede de vigilância. O país adotou uma definição de casos suspeitos de maior gravidade, a Síndrome Respiratória Aguda Grave (SRAG), e passou a orientar as ações de vigilância e controle prioritariamente para este grupo de pacientes. Quase 50 mil casos de SRAG pelo vírus pandêmico foram confirmados, com mais de 2 mil óbitos. A taxa de mortalidade observada na Região Sul foi de 2,3 por 100.000 hab., três vezes maior que a registrada no Chile, de apenas 0,8/100.000 hab., provavelmente pelas diferenças de abordagens em relação ao tratamento com o antiviral oseltamivir, que teve estratégias radicalmente diferentes entre os dois países. Enquanto o Chile adotou o tratamento imediato de todos os casos de síndrome gripal, baseado na evidência que o A/H1N1pdm era praticamente o único subtipo circulante, o Brasil manteve uma recomendação restritiva de uso que limitou bastante o acesso da população ao medicamento. Observou-se um aumento na frequência de internações hospitalares por influenza e pneumonia na rede hospitalar do SUS, e o aumento da ocorrência de óbitos em gestantes, adultos jovens e portadores de comorbidades, especialmente nos estados do sul do país (BRASIL, 2010i e 2013m).

Em 2010 foi realizada ampla campanha de vacinação contra o vírus pandêmico, tendo como grupo alvo as mulheres grávidas, as crianças menores de dois anos, trabalhadores da saúde, população indígena, pacientes de doenças crônicas e a população de 20 a 29 anos de idade (BRASIL, 2009h). Foram vacinados 81 milhões de pessoas, com uma cobertura vacinal de 88\% (BRASIL, 2011b). O vírus A/H1N1 pdm continuou sendo o vírus mais frequente, porém a o número de casos graves e de internações hospitalares por pneumonias e influenza foram inferiores ao ano anterior. 
Em 2011 foram tomadas medidas para ampliar a vigilância de influenza, por meio do monitoramento dos vírus respiratórios circulantes na comunidade e dos que produzem casos graves de SRAG. Em 2012, de forma semelhante ao observado no Texas, México e em algumas áreas da América do Sul, houve uma recirculação do A/H1N1 pdm nos estados da Região Sul produzindo casos de SRAG e óbitos, ainda que com muito menor magnitude do que a observada em 2009. A análise dos óbitos ocorridos demonstrou que ainda persistem dúvidas e problemas de manejo clínico dos casos de influenza entre os profissionais de saúde, apesar da revisão do protocolo de tratamento realizada em 2011 para adequá-lo às recomendações internacionais e da distribuição ampla de oseltamivir aos estados. A grande maioria dos óbitos (92\%) ou não recebeu o medicamento ou o recebeu tardiamente (BRASIL, 2013m).

\subsection{2 | Infecções Hospitalares}

As infecções decorrentes de intervenções dos serviços de saúde têm elevada incidência no país. Uma proporção importante delas é ocasionada por bactérias resistentes a um ou mais agentes antimicrobianos. O sistema de vigilância epidemiológica das infecções hospitalares no Brasil é coordenado pela Agência Nacional de Vigilância Sanitária (ANVISA). Em geral, a participação dos estados e municípios é limitada. Muitos deles nem mesmo recebem informações de parte dos hospitais. Não existe um sistema de informações rotineiras de base nacional sobre as infecções hospitalares. Em inquérito que incluiu 182 hospitais com unidades de tratamento intensivo (UTI), observou-se uma taxa de infecção hospitalar de 9\%, com uma letalidade de 14,4\%, entre os pacientes internados em UTI (SANTOS, 2006). Análise dos dados de 2010, realizada pelo CVE/SES-SP, a taxa de infecção hospitalar em cirurgias limpas foi de 0,91\%, e em UTI 16,6\% (SÃO PAULO, SES, 2010). Em anos recentes tem se avolumado o número de registros de surtos de infecções hospitalares e aglomerados de óbitos em serviços de saúde. Merece nota o grande surto de infecções por micobactérias não tuberculosas de crescimento rápido, que se iniciou em 2002. Mais de 2.600 casos foram confirmados, em 23 estados do país, sendo que 98\% dos casos estavam concentrados em 10 estados. O Rio de Janeiro foi responsável por 44\% dos casos. O pico do surto ocorreu em 2007, ano em que foram registrados quase mil casos (BRASIL, 2011c).

\section{6 | A RESPOSTA BRASILEIRA ÀS DOENÇAS TRANSMISSÍVEIS E AS PERSPECTIVAS PARA AS PRÓXIMAS DUAS DÉCADAS}

Até 1999, parte das ações de vigilância epidemiológica das doenças transmissíveis, em especial das doenças de transmissão vetorial, era de execução direta pelo nível federal de governo. As Secretarias Estaduais de Saúde já executavam, 
de forma compartilhada, as ações de vigilância e controle das doenças preveníveis por vacinação, da doença meningocócica, da tuberculose, da hanseníase e de algumas outras doenças. Os municípios não tinham atribuições formais neste campo, à exceção do controle de algumas zoonoses. Com a criação do SUS, em 1990, algumas capitais de estados e municípios de maior porte passaram a desenvolver ações de vigilância e controle por iniciativa própria. O nível federal apoiava os estados e municípios mediante a celebração de convênios específicos para determinadas doenças e programas. Em 1999, iniciou-se o processo de descentralização das ações de vigilância e controle de doenças (BARBOSA DA SILVA JR, 2004).

Esse processo incluiu a descentralização para estados e municípios de equipamentos e recursos humanos federais, como também dos recursos financeiros para sua execução. Foi instituído um mecanismo de transferência regular e direta de recursos, cujo montante passou a ser calculado tendo como base o perfil epidemiológico, a superfície da unidade federada, a sua população e a sua localização, dentre as grandes regiões do país. Foram produzidos também instrumentos unificados de programação e monitoramento, com base em indicadores operacionais e epidemiológicos, para o acompanhamento do desempenho das unidades federadas. O processo de descentralização teve uma forte adesão dos estados e municípios (BARBOSA DA SILVA JR, 2004).

O processo de descentralização trouxe consigo a incorporação de um novo conjunto de profissionais, em sua maioria inseridos nas secretarias municipais de saúde. Ampliou-se a base de unidades notificantes, assim como o número de serviços envolvidos com as ações de vigilância e controle. Entretanto, com o grande número de municípios existentes e a importante desigualdade que existe entre eles de capacidade técnica para ofertar ações e serviços de vigilância em saúde, colocamse alguns desafios permanentes: fortalecer a capacidade das secretarias estaduais de assessorar e apoiar tecnicamente os municípios e construir em parceria com eles as ações regionais; garantir equipes capacitadas para desempenhar as ações; assegurar que atividades de vigilância, prevenção e controle de doenças integrem as prioridades da gestão; e integrar fortemente essas ações com a atenção primária de saúde.

Apesar desses desafios, os indicadores e dados disponíveis, revelam que o Brasil tem avançado muito em relação à vigilância, prevenção e controle das doenças transmissíveis, e a perspectiva para as próximas duas décadas apontam para uma continuidade desse avanço. Usando a categorização já utilizada nas seções iniciais deste capítulo, serão, em seguida, discutidas algumas tendências para o futuro.

Pode-se afirmar que a tendência para as doenças incluídas no primeiro grupo, aquelas que já cursam com uma diminuição em seus níveis de prevalência e incidência, é de que a tendência atualmente observada se intensifique. Todas as doenças preveníveis por vacinação que já vêm em declínio, provavelmente continuarão 
na tendência em curso, chegando à eliminação no país, e talvez mesmo à erradicação, se forem também alvo de ações em nível internacional. A poliomielite e o sarampo avançam no sentido de uma possível erradicação global. Em relação à primeira, coloca-se como etapa necessária no processo, a substituição da vacina atenuada pela inativada, e em relação à segunda, faz-se necessária à intensificação da vigilância e controle, especialmente em alguns países da Europa e Ásia, responsáveis hoje por um grande volume de casos e pela exportação deles às regiões onde a doença já teve sua transmissão autóctone interrompida. Em relação à difteria, o tétano e a coqueluche, o aperfeiçoamento da estratégia de vacinação, com aumento da homogeneidade e avaliações sobre o benefício de se ampliar a cobertura vacinal entre jovens e adultos poderiam ter impacto significativo na redução ainda mais veloz de sua incidência. No caso da coqueluche, a nova estratégia de vacinação com a DTP acelular em gestantes programada para 2013 pode inverter a tendência recente de aumento de casos em menores de um ano. A completa implantação da estratégia de vacinação contra a hepatite B, particularmente com aumento da cobertura da vacinação do recém nascido em todos os serviços de obstetrícia do país, e o aumento da vacinação de adultos jovens, também podem acelerar o controle da doença. A incidência de rubéola, caxumba (embora não se disponham de dados nacionais sobre ela) e as infecções pelo Haemophylus influenzae tipo B devem também permanecer em níveis mínimos, sem impacto à saúde pública. A incidência de infecções por rotavírus, pela Neisseria meningitidis sorogrupo C e Streptococcus pneumoniae também devem acentuar sua redução com o crescimento, a cada ano, de nova coorte de vacinados. Em relação aos dois últimos agentes, a queda esperada ocorrerá entre as crianças, pois os portadores adultos manterão os agentes em circulação, com a ocorrência de doença nas faixas etárias não vacinadas.

A influenza continuará a ser motivo de preocupação global, e também no Brasil, pela possibilidade de surgimento de novos subtipos que iniciem nova pandemia. O fortalecimento da vigilância da influenza, incluindo os subtipos circulantes, é essencial para a rápida detecção de mudanças nos padrões da doença. O início da produção nacional da vacina contra influenza, pelo Instituto Butantan, em 2012, e a possibilidade do uso de adjuvantes, que potencializam a resposta imune à vacina, sinalizam que o país contará com maior disponibilidade desta vacina nos próximos anos, podendo-se avaliar a adoção de novas estratégias e de ampliação para outros grupos em que as evidências o justifiquem. Entretanto, como não se prevê, no curto prazo, o desenvolvimento de uma vacina de alta eficácia, capaz de impedir a circulação do vírus de influenza, o fortalecimento da vigilância e da preparação dos serviços de saúde durante os meses de inverno serão atividades essenciais para reduzir a morbimortalidade associada à influenza. A melhoria das condições de vida, aliada à vacinação contra influenza e contra o Streptococcus pneumoniae sinalizam para uma continuidade futura na tendência de redução da ocorrência de infecções respiratórias e de pneumonias. 
Como a vacina contra febre amarela não induz à imunidade de rebanho contra o ciclo silvestre da doença, o país deverá manter a vacinação contra febre amarela para os menores de um ano, em todas as áreas com circulação permanente do vírus, a realização de campanhas periódicas de revacinação e fortalecer as estratégias especiais para trabalhadores migrantes e turistas que realizam atividades em matas. O Instituto Biomanguinhos, braço produtor de imunobiológicos da FIOCRUZ, vem trabalhando no desenvolvimento de vacinas menos reatogênicas contra a febre amarela. Com a disponibilização de uma vacina mais segura, a tomada de decisão sobre estratégias de ampliação da vacinação para todo o país será facilitada.

A incorporação de novas tecnologias, em especial da biologia molecular, vem permitindo um avanço notável da vacinologia. Novas vacinas já estão disponíveis, e outras estão em processo avançado de desenvolvimento. Dentre as vacinas já disponíveis, as vacinas contra hepatite A e varicela já estão com decisão de incorporação no calendário nacional do PNI a partir de 2013, o que produzirá impacto importante na carga dessas doenças. A vacina contra o HPV encontra-se em processo de estudo pelo Ministério da Saúde visando sua implantação a partir de 2014. Uma futura implantação da vacina tetravalente contra doença meningocócica (sorogrupos A, C, Y e W135) e a nova vacina contra a doença meningocócica sorogrupo B que se encontra em desenvolvimento poderão reduzir ainda mais a incidência da doença.

A análise da trajetória recente de incorporação de novas vacinas aos programas de vacinação universal no Brasil e do orçamento alocado à aquisição de vacinas demonstra que o país tem sido mais ágil do que no passado na incorporação de novas vacinas, e que vem apresentando uma curva ascendente na alocação de recursos ao programa. Essas tendências, se mantidas, possibilitarão a incorporação das vacinas já disponíveis e de outras, hoje em fase de desenvolvimento, sendo algumas delas de grande interesse para o país. Uma delas, a vacina contra dengue, poderá vir a ser uma alternativa do país para o controle desta doença emergente e de alto impacto social e sanitário. A existência de um parque produtor público de imunobiológicos e de instituições acadêmicas de excelência no campo das pesquisas em DIP permite ao Brasil uma maior autonomia nas decisões sobre o programa de imunizações, minimizando a dependência ao mercado internacional de vacinas. 0 PNI, programa executado pelas três esferas de gestão do SUS, vem demonstrando notável habilidade na incorporação de novas vacinas, o que exige disseminação de informações e programas de treinamento em larga escala para os profissionais das mais de 30 mil salas de vacina existentes no país e a preparação de toda a logística envolvida, incluindo-se maior capacidade de armazenagem na rede de frio, pois a maioria das novas vacinas tem apresentações de dose única.A incorporação das novas vacinas tem exigido investimento em todos os pontos da rede de frio. Outra questão a ser constantemente aperfeiçoada é a vigilância epidemiológica dos eventos adversos temporalmente associados às vacinas (EAPV). A ocorrência de EAPV sem 
a elucidação rápida e consistente das causas pode contribuir para a queda nas coberturas vacinais por produzir desconfiança sobre a segurança da vacina entre a população. A tendência à melhoria das condições de saneamento básico no país deverá se manter, proporcionando uma redução mais acentuada na ocorrência das doenças diarreicas e da hepatite A. Em relação a esta última, a melhoria do saneamento e a incorporação da vacina poderão reduzir sua incidência a níveis muito baixos. A cólera foi controlada no país e não se espera que haja uma reemergência no futuro próximo, sendo necessária, entretanto, a preservação das atividades de vigilância.

A manutenção da vigilância epidemiológica e entomológica é necessária para garantir que não haja a reintrodução da transmissão vetorial da doença de Chagas no Brasil. A transmissão vetorial continua a ocorrer em países limítrofes, como a Bolívia, a Argentina, o Peru, e outros, e o fluxo de veículos, cargas e pessoas, com o potencial de trazerem não apenas portadores da doença, mas também os vetores, representa uma permanente ameaça à manutenção da eliminação da transmissão vetorial da doença no país. Já a transmissão do Trypanosoma cruzi pela via alimentar na região Amazônica deverá continuar a ocorrer enquanto não se alterarem as características de coleta, do transporte, do preparo e do consumo do açaí, estes últimos de características domiciliares, e a resistência da população às medidas de higiene alimentar (pasteurização). O fortalecimento da vigilância epidemiológica dos quadros agudos de doença de Chagas possibilitará a detecção precoce de casos isolados e surtos, a intervenção sobre situações de risco e o seu tratamento oportuno com redução da letalidade.

Mantidas as tendências atuais, o país deverá eliminar a filariose linfática do seu último foco no país, a Região Metropolitana do Recife, e também a oncocercose, no extremo Norte, nos próximos anos. A raiva humana transmitida por animais domésticos deverá manter a tendência atual de acontecimento de raros casos e redução da área de circulação do vírus rábico, com evolução em direção a eliminação nos próximos anos. Já a raiva humana decorrente de agressões por animais silvestres, em especial dos morcegos, é de difícil eliminação. O aprimoramento da vigilância epidemiológica, mudanças de hábitos de algumas populações residentes em áreas silvestres, maior acesso à profilaxia pós-exposição, entre outras medidas podem mitigar os seus efeitos, reduzindo ou eliminando a ocorrência de casos humanos e a mortalidade por raiva no país.

A incidência e a mortalidade da tuberculose devem continuar sua tendência decrescente, em virtude das ações do programa de controle e da própria redução da pobreza que se observa no país. Entretanto, sua carga, ainda que com redução progressiva, provavelmente se concentrará cada vez mais na periferia pobre das grandes cidades e em populações muito vulneráveis, representando um desafio a exigir a implantação de estratégias apropriadas, como o teste rápido avaliado em Manaus e Rio de Janeiro em 2012 e que será ampliado progressivamente para todo o 
país a partir de 2013. A crescente integração das ações de diagnóstico, tratamento e busca de contatos com a rede de atenção primária de saúde também será fundamental para atingir adequadamente alguns desses grupos.

As doenças negligenciadas constituem um grupo de doenças infecciosas associadas à pobreza, para as quais, historicamente se conferia baixo grau de prioridade para o desenvolvimento de vacinas, medicamentos e kits diagnósticos, exatamente porque sua maior carga é concentrada em populações pobres. É um conceito relativamente impreciso, pois algumas das doenças aí consideradas, como a dengue, atualmente recebe um dos maiores volumes de investimento em escala global para o desenvolvimento de uma vacina. Em 2010, a OMS publicou o seu primeiro relatório sobre a situação das doenças negligenciadas no mundo (WHO, 2010). A OMS inclui 17 doenças ou grupos de doenças na categoria de negligenciadas. Delas, pelo menos doze ocorrem de forma endêmica no Brasil, algumas mais focalizadas, outras mais disseminadas, e com diferentes gradientes de carga. Algumas (dengue e leishmanioses) são consideradas emergentes ou reemergentes no país, outras (doença de Chagas, filariose linfática, oncocercose, raiva) estão em estágio avançado de controle e eliminação, uma, a esquistossomose, vem apresentando tendência decrescente mais acentuada, e outras (hanseníase, tracoma, cisticercose, hidatidose e geohelmintíases) apresentam tendência decrescente, embora menos acentuada, ou mesmo relativa estabilidade.

O panorama internacional e nacional em relação às doenças negligenciadas tem se modificado velozmente, nos anos recentes. Os países das Américas aprovaram resolução no Conselho Diretivo da OPAS, em 2009, se comprometendo a acelerar o processo de eliminação de várias dessas doenças; alianças globais foram formadas para fazer advocacia e mobilizar recursos de doadores públicos e privados; e definitivamente elas são incorporadas cada vez com maior força no cenário da saúde global (PAHO, 2009). No país, o lançamento do "Plano integrado de ações estratégicas de eliminação da hanseníase, filariose, esquistossomose e oncocercose como problema de saúde pública, tracoma como causa de cegueira e controle das geohelmintíases: plano de ação 2011-2015" colocou uma possibilidade sem precedentes de integração com a Estratégia de Saúde da Família e de colocação do enfrentamento dessas doenças como prioridade para o SUS. Esse novo cenário permite pensar que a eliminação e controle serão ainda mais acelerados nos próximos anos, reduzindo a carga desproporcional dessas doenças sobre as pessoas mais pobres. A redução da pobreza que vem se observando na última década também tende a impulsionar a redução da prevalência dessas doenças. A hidatidose e a cisticercose exigirão uma intervenção intersetorial, envolvendo a agricultura e abastecimento, a sanidade dos rebanhos, o controle do abate clandestino de animais para consumo humano, e a mudança de hábitos culturais da população. Para o controle da toxoplasmose também será necessária a implantação de ações integradas à agricultura e ao abastecimento. A ocorrência de febre tifoide deve manter o perfil de redução atual, auxiliado também pela melhoria do saneamento 
básico. Por outro lado, a ocorrência de casos de contaminação da cadeia alimentar com bactérias do gênero Salmonella deve continuar.

Como se trata de uma zoonose de roedores silvestres, a peste não é passível de erradicação, apesar da ocorrência de casos ser um evento raro. Os focos zoonóticos de peste podem ficar inativos por períodos muito longos, de até mais de uma década, e depois voltar a ocorrer transmissão entre os animais e deles ao homem. A vigilância epidemiológica precisa estar alerta e detectar eventuais episódios de reemergência da doença.

As micoses sistêmicas continuarão a ocorrer de forma endêmica no país. Seu modo de transmissão, a inalação de partículas infectantes dos fungos, presentes no meio ambiente, torna difícil o controle da transmissão. Uma resposta mais organizada, por parte do SUS, poderá estabelecer um melhor conhecimento da sua carga e dispersão do problema, facilitando a organização dos serviços de saúde para enfrentá-lo, de forma a reduzir a morbidade e mortalidade.

A redução da incidência e da mortalidade que vem se registrando nos anos recentes, bem como a existência de estratégias factíveis, permite pensar em possível eliminação da malária por P. falciparum no médio prazo. Para a malária por P. vivax será necessária a manutenção de alta prioridade para as ações descentralizadas de vigilância, diagnóstico e tratamento, além de ações preventivas nos projetos de desenvolvimento implantados na Amazônia para que se mantenha a atual tendência de redução, de forma sustentada, evitando-se a ocorrência de padrões cíclicos, como já observados no passado.

A sífilis e as outras doenças sexualmente transmissíveis tendem a permanecer endêmicas no país nas próximas décadas, podendo, entretanto, beneficiarse da ampliação da cobertura da Estratégia de Saúde da Família, especialmente entre a população mais vulnerável socialmente, o que pode impactar na redução de sua prevalência, no médio e longo prazo. Em relação à sífilis congênita, cuja incidência atual é de 3,3 casos por 1.000 nascidos vivos, para se alcançar a meta de eliminação da doença enquanto problema de saúde pública (incidência menor que 1 caso por 1.000 nascidos vivos) será necessário assegurar que a estratégia iniciada em 2011 de universalizar o diagnóstico e tratamento das gestantes e seus parceiros seja completada e mantida, com a melhoria significativa da qualidade da assistência pré-natal.

Em relação à Aids é provável que as tendências atuais se mantenham, sendo esperada uma alteração mais acentuada se novas ferramentas capazes de alterar radicalmente o curso da doença ou a sua prevenção, como uma vacina, forem desenvolvidas. Nesse cenário mais provável, o desafio para os próximos anos será continuar aperfeiçoando as estratégias de prevenção atualmente disponíveis, como acesso amplo aos preservativos, e desenvolver e implantar novas intervenções eficazes para promover a redução da transmissão entre os grupos mais vulneráveis, onde a 
prevalência é muito mais elevada do que na população em geral. O esforço atualmente em curso, de ampliar a detecção e instituir o tratamento em estágios cada vez mais precoces, que parece ser uma tendência que se consolida, pode trazer impacto não apenas para a melhoria da expectativa e qualidade de vida das pessoas infectadas, como auxiliar na redução da velocidade de transmissão entre determinados grupos, tendo em vista os resultados positivos que são obtidos entre as pessoas tratadas com ARV que apresentam uma quase eliminação da carga viral. Por outro lado, a maior sobrevida dos pacientes com Aids em razão do próprio sucesso do tratamento, implicará em cuidados especiais para essa população em razão dos efeitos colaterais dos ARV; do envelhecimento que propicia maior o surgimento de comorbidades de doenças crônicas não transmissíveis; da ampliação do número de pessoas em uso concomitante de terapêuticas imunossupressoras, em tratamentos oncológicos, em transplantes de órgãos; e outras condições relacionadas.

Embora a principal forma de transmissão do vírus, a sanguínea, tenha sido controlada, o país conviverá nas próximas duas décadas com um volume cada vez maior de novos diagnósticos de hepatite C. A demanda pelo tratamento de alto custo, por serviços especializados de acompanhamento de pacientes crônicos e por transplantes hepáticos deve aumentar, constituindo-se em desafio para o SUS.

As hantaviroses e a febre maculosa, como doenças não erradicáveis, deverão seguir ocorrendo no país, de maneira semelhante à atual, com a detecção de surtos localizados, de maiores ou menores proporções, relacionados à exposição ocupacional, em atividades de lazer, ou à exposição em ambientes periurbanos. Como não é possível o controle dos agentes etiológicos nos animais silvestres, reservatórios deles em ambas as doenças, as ações educativas e de manejo ambiental devem ser priorizadas. Uma vigilância epidemiológica sensível e ágil é uma condição necessária para a redução da letalidade.

A leptospirose também continuará a ocorrer de forma endêmica, com surtos sazonais após a ocorrência de inundações. A forma de uso e ocupação do solo urbano, aliada às precárias condições de saneamento ambiental, favorece tanto a proliferação de roedores quanto a ocorrência de enchentes. A ampliação das estratégias já implantadas de instituição de alertas para o diagnóstico e tratamento oportunos nessas condições de maior risco pode reduzir a letalidade pela doença.

As condições e determinantes que propiciam a ocorrência de epidemias de dengue não devem se alterar radicalmente em um futuro próximo. Nesse cenário, as ações de qualificação da vigilância entomológica e epidemiológica para identificar precocemente áreas sob maior risco; a melhoria continuada do trabalho de campo dos agentes de controle de endemias e de mobilização comunitária; e a consolidação das ações assistênciais que têm reduzido a mortalidade nos anos recentes, são essenciais para evitar ou reduzir o impacto produzido pela dengue. 
Por outro lado, novas ferramentas capazes de alterar o curso da doença, como a vacina contra dengue, podem tornar-se realidade em médio prazo pelo elevado volume de investimento que hoje é realizado, em escala internacional, para o seu desenvolvimento. Esse esforço reúne grandes produtores privados, produtores públicos, governos, instituições acadêmicas e organismos internacionais. Outras inovações, como a infecção com Wolbachia, também podem se transformar em ferramentas para uso nos programas de prevenção e controle, nos próximos anos.

Para que ocorra um melhor controle das leishmanioses nas próximas duas décadas também serão necessários novos instrumentos e estratégias, pois as atualmente disponíveis apresentam eficácia extremamente limitada. A leishmaniose visceral (LV) apresenta atualmente um importante ciclo de disseminação territorial e urbanização, em vários países da América Latina e no Brasil, impulsionado, em grande parte, pelas condições vividas nas periferias das grandes cidades. Novas vacinas caninas foram recentemente apresentadas, com estudos iniciais sugerindo alguma eficácia para evitar a transmissão, o que não era verificado nas antigas vacinas existentes no mercado. Se esses estudos se confirmarem, assim como os atualmente em curso sobre a efetividade das coleiras impregnadas, o panorama da LV poderá ser modificado, no médio e longo prazo.

O uso indiscriminado e excessivo de antibióticos, inclusive na produção pecuária, é o principal fator relacionado ao aumento da ocorrência de infecções hospitalares, cuja tendência é de expansão. A ampliação do uso de técnicas cirúrgicas e de diagnóstico, utilizando sondas e cateteres, pode propiciar a introdução de agentes infecciosos em diferentes tecidos. Consequentemente, este grupo de infecções deve continuar a ocorrer no país no futuro próximo. Nesse cenário o monitoramento da resistência, em âmbito hospitalar e comunitário, assim como as ações de controle das infecções hospitalares necessitam ser fortalecidos e ampliados. A melhor estruturação de um sistema de vigilância sobre esses eventos poderá fornecer subsídios para intervenções preventivas que eliminem os surtos hospitalares que ainda ocorrem com mais frequência do que seria esperado e forneçam evidências para o uso adequado de esquemas terapêuticos com antibióticos. A exigência de receita médica para a compra de antibióticos implementada pela ANVISA constituiu-se em passo importante na utilização racional dos antibióticos, e necessita ser desdobrado em futuras iniciativas visando o controle da resistência dos agentes infecciosos aos fármacos usados no seu tratamento.

A ampliação da capacidade de detecção e investigação de surtos de doenças transmitidas por alimentos (DTA), que tem sido verificada nos últimos anos, deverá propiciar um melhor conhecimento sobre a carga real desses eventos e orientar ações para reduzir sua carga. Mesmo com a melhoria das condições sanitárias e dos processos de produção de alimentos, as DTA provavelmente continuarão a ser um problema emergente no Brasil nas próximas décadas. 
O agente etiológico da Febre do Nilo Ocidental (FNO) já foi detectado em reservatórios animais no Brasil e em países vizinhos. Arbovirose do velho mundo, a FNO é endêmica na África, Oriente Médio, e em partes da Ásia e da Europa. Em 1999 a doença emergiu em Nova Iorque (EUA), a partir de onde se disseminou para quase todos os estados norte-americanos, Canadá e México, onde apresenta transmissão continuada. Houve detecção de casos também, de forma esporádica, em algumas ilhas do Caribe e na América Central e do Sul. Até o momento não se identificaram casos humanos no Brasil, mas a presença do agente etiológico em animais sinaliza para uma possível ocorrência no futuro. De forma semelhante, a circulação de outros arbovírus já foi identificada no país, em reservatórios animais, em casos autóctones ou surtos, ou ainda em casos importados, evidenciando a possibilidade de emergência dessas doenças infecciosas. Já foi descrita no país a ocorrência de casos autóctones de doença pelos vírus Rocio, Sabiá, Saint Louis, Oropuche, Mayaro, e outros.

No início de 2003 o mundo foi surpreendido com a disseminação internacional de um quadro sindrômico respiratório grave, que posteriormente teve a sua etiologia identificada como um novo agente infeccioso, uma variante zoonótica do Coronavírus, que fez o salto entre o seu reservatório animal e os seres humanos, e veio a causar a primeira pandemia do século XXI. Embora tenha apresentado disseminação limitada, com a ocorrência global de 8 mil casos, com detecção em cerca de 30 países, entre os quais sete com o estabelecimento de cadeias de transmissão autóctone, e uma letalidade de 10\%, a ocorrência da Síndrome Respiratória Aguda Grave pelo Coronavírus (SRAG-CoV, ou SARS, pela sua sigla em inglês) demonstrou a fragilidade do então vigente sistema internacional de detecção baseado na notificação de uma lista limitada de doenças conhecidas e dependentes exclusivamente da comunicação oficial. A emergência da SRAG-CoV trouxe à ordem do dia a necessidade de revisão dos instrumentos disponíveis para a rápida detecção e o controle da disseminação internacional de doenças. Essa percepção global acelerou o processo de revisão do Regulamento Sanitário Internacional, que já perdurava por mais de 10 anos, e que foi concluído e aprovado na Assembleia Mundial da Saúde realizada em 2005. O novo Regulamento, conhecido como RSI-2005, entrou em vigência a partir de julho de 2007 produzindo mudanças importantes no sistema de vigilância global. Passou-se de uma lista de três doenças de notificação compulsória internacional (cólera, febre amarela e peste) para a notificação de qualquer emergência em saúde pública de interesse internacional (ESPIN) e para a possibilidade de utilizar qualquer fonte de informação. Cada estado membro da OMS assumiu o compromisso de estabelecer oficialmente um ponto focal para o RSI-2005, que serve para comunicações oficiais e verificações de rumores; desenvolver as capacidades básicas de detecção,investigação e resposta às potenciais ESPIN, bem como avaliá-las em 24 horas após sua detecção, submetendo-as ao algoritmo de decisão de notificação internacional; e se necessário, notificá-las à OMS, dentro deste prazo. Outro diferencial do RSI-2005 é que os governos nacionais deixam de ser a única fonte de notificação, ficando a OMS autorizada a buscar, ativamente, a 
identificação de notícias e rumores na imprensa e na rede mundial de computadores, entre outras fontes. A partir de qualquer identificação, a OMS solicita a confirmação da ocorrência ao país. Esse procedimento aumenta consideravelmente a sensibilidade do sistema global de detecção e impede a postergação da comunicação oficial de surtos e epidemias. É reconhecido que o RSI2005- estabeleceu maior transparência na comunicação e compartilhamento de informações entre os países, tendo sido fundamental para o acompanhamento e resposta diante da primeira grande ESPIN desde sua entrada em vigor, a pandemia de influenza de 2009 (WHO, 2008).

O Brasil antecipou-se à exigência internacional e implantou no Ministério da Saúde, em 2004, o Centro de Informações Estratégicas em Vigilância em Saúde (CIEVS), com o propósito de coordenar as ações de vigilância e resposta às emergências em saúde pública, e atuar como ponto focal nacional do RSI. O CIEVS também utiliza a detecção passiva, por meio da comunicação oficial das secretarias estaduais de saúde e detecção ativa, buscando rumores e notícias sobre potenciais emergências de saúde pública. O Ministério também apoiou a implantação descentralizada dessas estruturas, contando-se, em 2011, com CIEVS em cada uma das unidades federadas e em 24 das 26 capitais estaduais. Nos três primeiros anos de funcionamento da rede CIEVS, 663 potenciais emergências em saúde pública de interesse nacional foram detectadas e investigadas (FIGUEIREDO, 2006). Outra iniciativa importante para aumentar a capacidade de detecção e resposta foi a implantação, em 2000, do Programa de Epidemiologia Aplicada aos Serviços de Sistema Único de Saúde (EPISUS), que se iniciou como uma parceria do Ministério da Saúde com os Centros de Controle e Prevenção de Doenças dos Estados Unidos (CDC), voltado à formação de profissionais especializados na investigação e resposta aos surtos, epidemias, e emergências em saúde pública. Nestes doze anos de existência, agora exclusivamente organizado pelo Ministério da Saúde, mais de 100 profissionais de saúde foram formados, a maioria deles inserida nos serviços de vigilância em saúde na rede do SUS. Investimentos de vulto foram feitos também no aprimoramento da rede de laboratórios de saúde pública, na rede de serviços de verificação de óbitos, e na rede de núcleos hospitalares de epidemiologia, com o propósito de assegurar maior abrangência, sensibilidade, especificidade e oportunidade às ações de vigilância em saúde no país. Recentemente, a publicação do Decreto 7.616, de 17 de novembro de 2011, que dispôs sobre a declaração de Emergência em Saúde Pública de Importância Nacional - ESPIN e institui a Força Nacional do Sistema Único de Saúde - FN-SUS, estabeleceu novos, e mais poderosos, instrumentos legais para organizar a resposta do SUS às emergências de qualquer natureza que possam impactar a saúde da população (BRASIL, 2011c).

Muitos foram os avanços na vigilância e controle de doenças transmissíveis no Brasil nos últimos anos. A mortalidade por doenças transmissíveis caiu, e o perfil de ocorrência delas hoje é completamente distinto daquele de duas décadas atrás. Algumas doenças foram controladas, algumas estão em processo avançado de controle. Outras, porém, ainda persistiram como problemas importantes de saúde pública, e 
outras ainda emergiram ou reemergiram. Todos esses processos continuarão a ocorrer nas próximas duas décadas. Se por um lado, é esperado que as doenças para as quais se dispõe de mecanismos eficazes de prevenção e controle continuem a diminuir sua importância, é certo também que, inevitavelmente, no país e em escala global, novas doenças surgirão, ressurgirão ou apresentarão novas características e comportamento, desafiando a capacidade de resposta dos sistemas de saúde.

Para fazer frente a essa situação é necessário colocar-se como uma das prioridades dos sistemas de saúde contar com uma rede de serviços de vigilância e resposta às doenças transmissíveis e às emergências de saúde pública. A própria percepção social, ainda que na maioria das vezes equivocada, de que praticamente todas as DIP encontram-se erradicadas ou em processo de erradicação, pela redução da morbimortalidade e pelos avanços tecnológicos obtidos nas últimas décadas, também contribui para aumentar a expectativa e a exigência sobre a capacidade de preparação para o enfrentamento dessas questões nas próximas duas décadas.

Para estar bem preparado para responder a esses desafios, é necessário que se reconheça o caráter de ação estratégica para o Estado das atividades de vigilância e resposta às emergências de saúde pública; que se busque o constante fortalecimento dos serviços de vigilância em saúde, prevenção e controle de doenças em todos os entes federativos, de acordo com o seu porte e nível de complexidade, com equipes de profissionais qualificados e estáveis; que se aperfeiçoe a organização de uma rede hierarquizada de serviços assistenciais especializados em doenças transmissíveis, tanto ambulatoriais quanto hospitalares e que atuem integrados com os serviços de vigilância; que a rede de laboratórios de saúde pública esteja em permanente evolução técnica; que a integração das ações de vigilância se dê em todos os níveis da rede assistencial pública e privada; e que se estabeleça uma adequada formação de saúde, desde a graduação, formando profissionais conhecedores das doenças mais prevalentes em nosso país, inclusive da sua diversidade regional, e das ações que devem ser adotadas no âmbito da atenção individual e da saúde pública, de forma a garantir a pronta detecção e uma resposta oportuna a todas as emergências em saúde pública que o país venha a enfrentar. 


\section{7 | REFERÊNCIAS BIBLIOGRÁFICAS}

AGAPEJEV, S. Aspectos clínicos e epidemiológicos da neurocisticercose no Brasil. ArqNeuropsiquiatr 2003, 61: 822-8.

ALONSO, WJ; VIBOUD, C; SIMONSEN, L; HIRANO, EW; DAUFENBACH LZ \& MILLER MA. Seasonality of influenza in Brazil: a traveling wave from the Amazon to the subtropics. Am J Epidemiol 2007, 165:1434-42.

ARAÚJO JD. Polarização epidemiológica no Brasil. 1992, Informe Epidemiológico do SUS 1(2): 5-16.

AYRES AR \& SILVA GA. Cervical HPV infection in Brazil: a systematic review. Rev Saúde Pública 2010, 44(5): 963-74.

BALTER. S. et al. Epidemicnephritis in Nova Serrana, Brazil. Lancet 2000, 355:1776-80.

BANIC, DM., et al. Impact of 3 years ivermectin treatment on oncocerciasis in Yanomami communities in the Brazilian Amazon.ActaTropica 2009, 112: 125-130.

BARBOSA DA SILVA JR., J. Epidemiologia em serviço: uma avaliação de desempenho do Sistema Nacional de Vigilância em Saúde. Tese de Doutorado. Campinas, 2004.

BARBOSA DA SILVA JR, J. As doenças transmissíveis no Brasil, tendências e novos desafios para o Sistema Único de Saúde, in: Ministério da Saúde/Secretaria de Vigilância em Saúde, Saúde Brasil 2008, 20 anos do Sistema Único de Saúde no Brasil. Brasília, 2009, pp 281-309.

BARRETO ML \& CARMO EH. Padrões de adoecimento e de morte na população brasileira: os renovados desafios para o Sistema Único de Saúde. 2007, Ciência e Saúde Coletiva 12 (Supl): 1779-1790.

BARRETO, ML; et al. Community-based monitoring of diarrhoea in urban Brazil children: incidence and associated pathogens. Trans R Soc Trop Med Hyg 2006, 100:234-42.

BARRETO, ML; et al. Effect of city-wide sanitation programme on reduction in rate of childhood diarrhoea in northeastern Brazil: assessment by two cohort studies. Lancet 2007, 370: 1622-28.

BARRETO, ML; et al. Successes and failures in the control of infectious diseases in Brazil: social and environmental context, policies, interventions and research needs. Lancet 2011, 377: 18771889.

BRASIL. Agência Nacional de Vigilância Sanitária/ANVISA. Relatório descritivo de investigação de casos de infecções por micobactérias de não tuberculosas de crescimento rápido (MCR) no Brasil, no período de 1998 a 2009. Brasília, 2011c. Acessível em http://portal.anvisa.gov.br/ wps/wcn/connect/d682c3004653b39eb545bf0ce2062da6/relatorio_descrito_mcr_16_02_11.pdf.

BRASIL. MINISTÉRIO DA SAÚDE. Centro Nacional de Epidemiologia. Surto de doença diarréica por Cyclosporacayetanensis em Antonina - PR. Boletim Epidemiológico Eletrônico 2002b, 2(7):1-3.

BRASIL. MINISTÉRIO DA SAÚDE. Secretaria de Vigilância em Saúde. Investigação de casos suspeitos de botulismo associado ao consumo de carne suína em lata com preparo caseiro, Mato Grosso, 2002. Boletim Epidemiológico Eletrônico 2002a, 2(4):1-2. 
BRASIL. MINISTÉRIO DA SAÚDE. Secretaria de Vigilância em Saúde. Surto de raiva humana transmitida por morcegos no município de Portel - PA, março/abril de 2004. Boletim Eletrônico Epidemiológico 2004, 4(6):1-5.

BRASIL. MINISTÉRIO DA SAÚDE. Secretaria de Vigilância em Saúde. Consenso Brasileiro em Doença de Chagas. Rev Soc Bras Med Trop 2005, 38 (Supl 3): 1-29. (2005a).

BRASIL. MINISTÉRIO DA SAÚDE. Secretaria de Vigilância em Saúde. Vigilância epidemiológica das doenças transmitidas por alimentos no Brasil 1999-2004. Boletim Epidemiológico Eletrônico 2005, 5(6):1-7. (2005b).

BRASIL. MINISTÉRIO DA SAÚDE. Secretaria de Vigilância em Saúde. Surto da síndrome cardiopulmonar por hantavírus no Distrito Federal e Goiás, maio a setembro de 2004. Boletim Eletrônico Epidemiológico 2005, 5(1): 1-5. (2005c).

BRASIL. MINISTÉRIO DA SAÚDE. Secretaria de Vigilância em Saúde. Raiva humana transmitida por morcegos no Alto Turi - MA, julho/setembro de 2005. Boletim Eletrônico Epidemiológico 2006, 6(2):1-5. (2006a).

BRASIL. MINISTÉRIO DA SAÚDE. Secretaria de Vigilância em Saúde. Análise da situação da tuberculose no Brasil. In: MINISTÉRIO DA SAÚDE/Secretaria de Vigilância em Saúde. Saúde Brasil 2005: uma análise da situação de saúde. Brasília: Ministério da Saúde, 2006, pp 719-753. (2006b).

BRASIL. MINISTÉRIO DA SAÚDE. Secretaria de Vigilância em Saúde/Programa Nacional de DST e Aids. Manual de controle: doenças sexualmente transmissíveis. Brasília: Ministério da Saúde, $4^{\mathrm{a}}$ edição, 2006, 142 pp. (2006c).

BRASIL. MINISTÉRIO DA SAÚDE. Secretaria de Vigilância em Saúde. Manual dos Centros de Referência para Imunobiológicos Especiais. $3^{a}$ Ed. Brasília: Ministério da Saúde, 2006, 188p. (2006d).

BRASIL. MINISTÉRIO DA SAÚDE. Secretaria de Vigilância em Saúde. Manual de Vigilância da Leishmaniose Visceral. $1^{\mathrm{a}}$ ed, $3^{\mathrm{a}}$ reimpressão, Brasília: Ministério da Saúde, 2006, 120 pp. (2006e).

BRASIL. MINISTÉRIO DA SAÚDE. Secretaria de Vigilância em Saúde. Manual de Vigilância da Leishmaniose Tegumentar Americana. 2ª ed, Brasília: Ministério da Saúde, 2007, 180pp.

BRASIL. MINISTÉRIO DA SAÚDE. Secretaria de Vigilância em Saúde. Casos confirmados por unidade federada, Brasil, 1980-2005. Disponível em www.saude.gov.br/portal/arquivos/zip/ dnc_uf_agravos_todas.zip. Acesso em: 12 jul 2008. (2008a)

BRASIL. MINISTÉRIO DA SAÚDE. Secretaria de Vigilância em Saúde. Investigação de casos de meningite eosinofílica causada pela infecção por Angyostrongyluscantonensis, Espírito Santo, Brasil. Boletim Epidemiológico Eletrônico 2008, 8(18):1-5. (2008b).

BRASIL. MINISTÉRIO DA SAÚDE. Secretaria de Vigilância em Saúde. Guia de Vigilância Epidemiológica, caderno 10:19-30, Brasília: Ministério da Saúde, 7ª Ed, 2009. (2009a).

BRASIL. MINISTÉRIO DA SAÚDE. Secretaria de Vigilância em Saúde. Guia de Vigilância Epidemiológica e Eliminação da Filariose Linfática. Brasília: Ministério da Saúde, 2009, 82pp. (2009b).

BRASIL. MINISTÉRIO DA SAÚDE. Secretaria de Vigilância em Saúde. Nota técnica sobre as mudanças no tratamento da tuberculose no Brasil para adultos e adolescentes, 2009. 
Disponível em http://portal.saude.gov.br/portal/arquivos/pdf/nota_tecnica_versao_28_de_ agosto_v_5.pdf. Acesso em: 30 jun 2011. (2009c).

BRASIL. MINISTÉRIO DA SAÚDE. Secretaria de Vigilância em Saúde. Guia de Vigilância Epidemiológica, caderno 8:1-14, Brasília: Ministério da Saúde, $7^{a}$ ed, 2009. (2009d).

BRASIL. MINISTÉRIO DA SAÚDE. Secretaria de Vigilância em Saúde. Guia de Vigilância Epidemiológica, caderno 8:1-14. Brasília: Ministério da Saúde, 7ª ed, 2009. (2009e).

BRASIL. MINISTÉRIO DA SAÚDE. Secretaria de Vigilância em Saúde. Guia de Vigilância Epidemiológica, caderno 8:15-32. Brasília: Ministério da Saúde, 7ª ed, 2009. (2009f).

BRASIL. MINISTÉRIO DA SAÚDE. Secretaria de Vigilância em Saúde. Guia de Vigilância Epidemiológica, caderno 12:1-14. Brasília: Ministério da Saúde, $7^{a}$ ed, 2009. (2009g).

BRASIL. MINISTÉRIO DA SAÚDE. Secretaria de Vigilância em Saúde. Estratégia nacional de vacinação contra o vírus influenza pandêmico (H1N1), 2009. Disponível em www.conass.org. br/arquivos/file/informetecnico_05_03.pdf. Acesso em 08 jul 2011. (2009h)

BRASIL. MINISTÉRIO DA SAÚDE. Secretaria de Vigilância em Saúde. Situação epidemiológica das zoonoses de interesse para a saúde pública: doença de Chagas aguda. Boletim Eletrônico Epidemiológico 2010, 10(2): 10-11. (2010a).

BRASIL. MINISTÉRIO DA SAÚDE. Secretaria de Vigilância em Saúde. Situação epidemiológica das zoonoses de interesse para a saúde pública: raiva. Boletim Eletrônico Epidemiológico 2010, 10(2): 7-9. (2010b).

BRASIL. MINISTÉRIO DA SAÚDE. Secretaria de Vigilância em Saúde/Departamento de DST, Aids e Hepatites Virais. Boletim epidemiológico DST/AIDS 7(1), janeiro a junho de 2010c.

BRASIL. MINISTÉRIO DA SAÚDE. Secretaria de Vigilância em Saúde. Guia de Vigilância Epidemiológica. $7^{\mathrm{a}}$ Ed, Caderno 4: 37-47, Brasília, 2010d.

BRASIL. MINISTÉRIO DA SAÚDE. Secretaria de vigilância em saúde. Guia de Vigilância Epidemiológica, $7^{a}$ Ed. Brasília, 2010. Caderno 7: 29-37. (2010e).

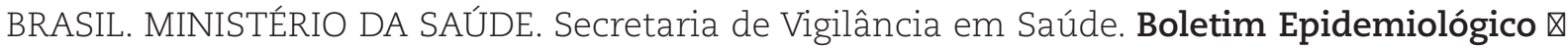
Hepatites Virais 1(1). Brasília: Ministério da Saúde, $2010 f$.

BRASIL. MINISTÉRIO DA SAÚDE. Secretaria de Vigilância em Saúde. Investigação de surto de botulismo alimentar em Coruripe/AL, em abril de 2009. Boletim Epidemiológico Eletrônico 2010, 10(7):1-4. (2010g).

BRASIL. MINISTÉRIO DA SAÚDE. Secretaria de Vigilância em Saúde. Situação epidemiológica das zoonoses de interesse para a saúde pública: febre maculosa. Boletim Eletrônico Epidemiológico 2010, 10(2):16-17. (2010h).

BRASIL. MINISTÉRIO DA SAÚDE. Secretaria de Vigilância em Saúde. Influenza pandêmica (H1N1) 2009 - Análise da situação epidemiológica e da resposta no ano de 2009. Boletim Epidemiológico Eletrônico 2010, 10(1):1-21. (2010i).

BRASIL. MINISTÉRIO DA SAÚDE. Secretaria de Vigilância em Saúde. Febre tifóide, informações técnicas. Disponível em http://portal.saude.gov.br/portal/saude/profissional/visualiza_texto. cfm?idtxt=31. Acesso em: 25 jun 2011. (2011a). 
BRASIL. MINISTÉRIO DA SAÚDE. Secretaria de Vigilância em Saúde. Balanço parcial da vacinação contra a gripe A(H1N1). Disponível em http://portal.saude.gov.br/portal/arquivos/ pdf/gripe_180610.pdf. Acesso em: 08 jul /2011. (2011b).

BRASIL. MINISTÉRIO DA SAÚDE, Secretaria de Vigilância em Saúde. Sistema de Informações de Mortalidade (atualizado em 18/06/2012). (2012a).

BRASIL. MINISTÉRIO DA SAÚDE. Secretaria de Vigilância em Saúde. Plano integrado de ações estratégicas de eliminação da hanseníase, filariose, esquistossomose e oncocercose como problema de saúde pública, tracoma como causa de cegueira e controle das geohelmintíases: plano de ação 2011-2015. Brasília: Ministério da Saúde, 2012.100 p. (2012b).

BRASIL. MINISTÉRIO DA SAÚDE. Secretaria de Vigilância em Saúde. Boletim Epidemiológico, Especial Tuberculose. Volume 43, março — 2012. (2012c).

BRASIL. MINISTÉRIO DA SAÚDE. Secretaria de Vigilância em Saúde. Boletim Epidemiológico Aids e DST - 2012. Versão Preliminar. Disponível em http://www.aids.gov.br/publicacao/2012/ boletim-epidemiologico-aids-e-dst-2012. Acesso em 7 abr. 2013. (2012d).

BRASIL. MINISTÉRIO DA SAÚDE, Secretaria de Vigilância em Saúde. Tópicos de Vigilância em Saúde - Dengue. Disponível em http://portal.saude.gov.br/portal/arquivos/pdf/dados_ dengue_obitos_2012_at032013.pdf.Acesso em 21 mar. 2013. (2013a).

BRASIL, MINISTÉRIO DA SAÚDE. Secretaria de Vigilância em Saúde. Informe Técnico Campanha de Vacinação contra a Influenza 2013. Disponível em http://portal.saude.gov.br/ portal/arquivos/pdf/informe_tecnico_campanha_influenza_2013_svs_pni.pdf. Acesso em 13 abr. 2013. (2013b).

BRASIL. MINISTÉRIO DA SAÚDE. Secretaria de Vigilância em Saúde. Boletim Epidemiológico Hanseníase. Brasília, 2013 [no prelo]. (2013c).

BRASIL. MINISTÉRIO DA SAÚDE. Secretaria de Vigilância em Saúde. Situação da Tuberculose no Brasil. Apresentação realizada no evento relativo ao Dia Mundial de Luta contra a Tuberculose 2013. (2013d).

BRASIL. MINISTÉRIO DA SAÚDE. Secretaria de Vigilância em Saúde. Tópicos de Vigilância em Saúde - Malária. Disponível em http://portal.saude.gov.br/portal/saude/profissional/area. cfm?id_area=1526. Acesso em: 12 abr. 2013. (2013e).

BRASIL. MINISTÉRIO DA SAÚDE. Secretaria de Atenção à Saúde. Diretrizes Gerais e Operacionais da Rede Cegonha. Disponível em http://portal.saude.gov.br/portal/saude/gestor/visualizar_ texto.cfm?idtxt=37082. Acesso em: 4 ab.r 2013. (2013f).

BRASIL. MINISTÉRIO DA SAÚDE. Secretaria de Vigilância em Saúde. Tópicos de Vigilância em Saúde - Varicela. Disponível em http://portal.saude.gov.br/portal/saude/profissional/area. cfm?id_area=1660. Acesso em: 28 mar. 2013. (2013g).

BRASIL. MINISTÉRIO DA SAÚDE. Secretaria de Vigilância em Saúde. Tópicos de Vigilância em Saúde - Dengue. Situação epidemiológica. Disponível em http://portal.saude.gov.br/portal/ arquivos/pdf/dados_dengue_obitos_2012_at032013.pdf. Acesso em 25 mar. 2013. (2013h).

BRASIL. MINISTÉRIO DA SAÚDE. Secretaria de Vigilância em Saúde. HIV/Aids no Brasil 2012. [apresentação realizada por ocasião do Dia Mundial de Luta contra a Aids, com base nos dados do Boletim Epidemiológico em elaboração]. (2013i). 
BRASIL. MINISTÉRIO DA SAÚDE. Secretaria de Vigilância em Saúde. Tópicos de Vigilância em Saúde - Leishmaniose Visceral. Disponível em http://portal.saude.gov.br/portal/saude/ profissional/area.cfm?id_area=1561. Acesso em: 14 ab.r 2013. (2013j).

BRASIL. MINISTÉRIO DA SAÚDE. Secretaria de Vigilância em Saúde. Tópicos de Vigilância em Saúde - Febre Amarela. Disponível em http://portal.saude.gov.br/portal/saude/profissional/ area.cfm?id_area=1552. Acesso em: 15 abr. 2013. (2013k).

BRASIL. MINISTÉRIO DA SAÚDE. Secretaria de Vigilância em Saúde. Protocolo Clínico e Diretrizes Terapêuticas para Hepatite Viral C e Coinfecções. Disponível em http://www.aids. gov.br/publicacao/2011/protocolo_clinico_e_diretrizes_terapeuticas_para_hepatite_viral_c_e_ coinfeccoes. Acesso em: 12 abr. 2013. (20131).

BRASIL. MINISTÉRIO DA SAÚDE. Secretaria de Vigilância em Saúde. Tópicos de Vigilância em Saúde: Influenza. Disponível em http://portal.saude.gov.br/portal/saude/profissional/area. cfm?id_area=1650. Acesso em 15 abr. 2013. (2013m).

BRASIL. PRESIDÊNCIA DA REPÚBLICA. Decreto 7.616, de 17 de novembro de 2011, que dispõe sobre a declaração de Emergência em Saúde Pública de Importância Nacional - ESPIN e institui a Força Nacional do Sistema Único de Saúde - FN-SUS. Disponível em http://www. planalto.gov.br/ccivil_03/_Ato2011-2014/2011/Decreto/D7616.htm. Acesso em: 15 abr. 2013. (2011c)

CAMPAGNA, AS; et al. Mortalidade por causas relacionadas à influenza em idosos no Brasil, 1999 a 2005. Epidemiol Serv Saúde 2009, 18:209-18.

CARMO, GMI; et al. Decline in diarrhea mortality and admissions after routine childhood rotavirus immunization in Brazil: a time-series analysis. Plos Med 2011, 8(4): e100124.

CARVALHO, MTB; et al. O Programa Nacional de Imunizações nos 20 anos do Sistema Único de Saúde, in: Ministério da Saúde/Secretaria de Vigilância em Saúde, Saúde Brasil 2008, 20 anos do Sistema Único de Saúde no Brasil. Brasília, 2009, pp 63-83.

CARVALHO, OS; et al. Prevalência de helmintos intestinais em três mesorregiões de Minas Gerais. Rev Soc Bras Med Trop 2002, 35(6): 597-600.

CENTERS FOR DISEASE CONTROL AND PREVENTION (CDC). Addressing emerging infectious diseases threats: a prevention strategy for the United States. 1994, CDC, Atlanta.

CENTERS FOR DISEASE CONTROL AND PREVENTION (CDC). Estimates of foodborne illnesses in the United States. www.cdc.gov/foodborne. Acesso em: 06 jul 2011.

CENTERS FOR DISEASE CONTROL AND PREVENTION (CDC). Cholera in Haiti: one year later. Disponível em http://www.cdc.gov/haiticholera/haiti_cholera.htm. Acesso em: 25 mar. 2013.

COSTA CHN. How effective is dog culling in controlling zoonotic visceral leishmaniasis? A critical evaluation of the science, politics and ethics behind this public health policy. Rev Soc Bras Med Trop 2011, 44(2):232-242.

DALCOMO, MP; ANDRADE, MKN \& PICON, PD. Tuberculose multirresistente no Brasil: histórico e medidas de controle. Rev Saúde Pública 2007, 41(Supl.1): 34-42.

DAUFENBACH, LZ; CARMO, EH; DUARTE, EC; CAMPAGNA, SA; TELES, CA. Morbidade hospitalar por causas relacionadas à influenza em idosos no Brasil, 1992 a 2006. Epidemiol Serv Saúde 2009, 18:29-44. 
DIMECH GS. Avaliação da efetividade da estratégia do tratamento diretamente observado (DOTS) no controle da tuberculose, Brasil, 2007. Dissertação de mestrado, Faculdade de Ciências Médicas da Santa Casa de São Paulo, 2010.

EDUARDO, MBP. et al. Diphyllobothriumspp: um parasita emergente em São Paulo, associado ao consumo de peixe cru, sushis e sashimis, São Paulo, março de 2005. BEPA 2005, 2(15):1-5.

FIGUEIREDO, GM. Breve histórico da emergência da hepatite B como problema de saúde pública. Jornal Brasileiro de AIDS 2006, 7 (6):273-320.

FONSECA, C; MORAES, JC \& BARATA, RB. O livro da meningite, uma doença sob a luz da cidade. São Paulo, Segmento Farma, 2004, 206p.

FONSECA, EOL. et al. Prevalência e fatores associados às geo-helmintíases em crianças residentes em municípios com baixo IDH no Norte e Nordeste brasileiros. Cad Saúde Pública 2010, 26(1): 143-152.

FORNAJEIRO, N. et al. Paracoccidioidomycosis epidemiological survey using gp43 in two cities of northwestern region of Paraná, Brazil. Rev Soc Bras Med Trop 2005, 38(2): 191-3.

FRENK, J. et al. La transición epidemiológica en América Latina. Bull Sanit Panam, 1991, 111(6): 485-496.

GONÇALVES, A.L.R. et al. Prevalence of intestinal parasites in preschool children in the region of Uberlandia, State of Minas Gerais. Rev Soc Bras Med Trop 2011, 44(2):191-193.

GUIBU, I.A. et al. Survival of AIDS patients in the Southeast and South of Brazil: analysis of the 1998-1999 cohort. Cad Saúde Pública 2011, 27(Supl 1):S79-S92.

HONÓRIO, N.A. et al. Spatial evaluation and modeling of dengue seroprevalence and vector density in Rio de Janeiro, Brazil. PLoS Neglected Tropical Diseases 2009, 3(11):e545.

INSTITUTE OF MEDICINE. Emerging Infections, Microbial Threats to Health in the United States. 1992, Washington, NationalAcademy Press, 294 pp.

INSTITUTE OF MEDICINE. Microbial Threats to Health: emergence, detection and response. 2003, Washington, NationalAcademy Press, 367pp.

KALMAR, E.M. et al. Paracoccidioidomycosis: an epidemiological survey in a pediatric population from the Brazilian Amazon using skin tests. Am J Trop Med Hyg 2004, 71(1):82-6.

KEW O.M. et al. Vaccine-derived polioviruses and the endgame strategy for global polio eradication. Annu Rev Microbiol 2005, 59:587-635.

KOMPALIC-CRISTO, A; BRITTO, C. \& FERNANDES, O. Diagnóstico molecular de toxoplasmose: revisão. J Bras Patol Lab Med 2005, 41(4):229-35.

LIMA, V.L.C. et al. Dengue: inquérito populacional para pesquisa de anticorpos e vigilância virológica no município de Campinas, São Paulo, Brasil. Cad Saúde Pública. 2007; 23(3):669-82.

LIPPMANN, A.S. et al. Prevalence, distribution and correlates of endocervical human papillomavirus types in Brazilian women. Int J STD AIDS 2010, 21(2): 105-09.

LOPES, M.F.C. et al. Inquérito epidemiológico do tracoma no Brasil, aprovado para publicação na Revista de Saúde Pública. 
LUNA, E.J.A. et al. Household survey of hepatitis B vaccine coverage among Brazilian children. Vaccine 2009, 27: 5326-5331.

LUNA, E.J.A. \& GATTÁS, V.L. Effectiveness of the Brazilian influenza vaccination policy, a systematic review. Rev Inst Med Trop Sao Paulo 2010, 52:175-181.

MARINS, J.R.P. et al. Dramatic improvement in survival among adult Brazilian AIDS patients. AIDS 2003, 17:1675-1682.

MASCARINI-SERRA, L.M. et al. Reductions in the prevalence and incidence of geohelminth infections following a city-wide sanitation program in a Brazilian urban centre. PLoS Neglected Tropical Diseases 2010, 4(2):e588.

MORAES-SOUZA, H. \& FERREIRA-SILVA, M.M. O controle da transmissão transfusional. Rev Soc Bras Med Trop 2011, 44 (Supl 2):64-67.

MOREIRA, A.P.V. Paracoccidioidomicose: histórico, etiologia, epidemiologia, patogênese, formas clínicas, diagnóstico laboratorial e antígenos. BEPA 2008, 5(51): 11-22.

MORENS, D.M; TAUBENBERGER, J.K \& FAUCI, A.D. The persistent legacy of the 1918 influenza virus. New Engl J Med 2009, 361:225-9.

MOURA, L. et al. Waterborne toxoplasmosis, Brazil, from field to gene. Emerging Infectious Diseases 2006, 12(2): 326-29.

NORMILLE, D. Avian influenza: flu virus research yields results but no magic bullet for pandemic. Science 2008, 319: 1178-79.

NOVEL SWINE-ORIGIN INFLUENZA A (H1N1) VIRUS INVESTIGATION TEAM. Emergence of a novel swine origin influenza A (H1N1) virus in humans. New Engl J Med 2009, 361: 1-10.

NYITRAY, A.G. et al. Prevalence and risk factors for anal human papillomavirus in men having sex with women: a cross-national study. J Infect Dis 2010, 201(10): 1498-1509.

OLIVEIRA-SILVA, M. et al. Human papillomavirus in Brazilian women with and without cervical lesions. J Virol 2011, 8(4) e-pub.

OMRAN, A.R. The epidemiologic transition theory: a theory of the epidemiology of population change. 1971, Milbank Mem Fund Q, 49(4):509-538.

OMRAN, A.R. The epidemiologic transition theory: a preliminary update. 1983, J Trop Ped, 29: 306-316.

ORGANIZAÇÃO DAS NAÇÕES UNIDAS (ONU). Global report: UNAIDS report on the global AIDS epidemic 2012. Disponível em http://www.unaids.org/en/resources/campaigns/20121120_ globalreport2012/globalreport/. Acesso em: 7 abr 2013.

ORGANIZACIÓN DE LAS NACIONES UNIDAS PARA LA AGRICULTURA Y ALIMENTACIÓN (FAO). Estimación del impacto económico de la equinococosis quística em el Cono Sur (Argentina, Brasil, Chile y Uruguay). 2007, FAO/RLC, acessível em www.paho.org/Spanish/AD/DPC/VP/ hidatidose-impacto-econ-07-fao.pdf.

ORGANIZACIÓN PANAMERICANA DE LA SALUD (OPAS). Centro Panamericano de Fiebre Aftosa OPS/PANAFTOSA. Hidatidosis, $3^{\mathrm{a}}$ Reunión del Proyecto Subregional Cono Sur de Control Y Vigilancia de La Hidatidosis, Informe Final. Porto Alegre, 2006. 62p. 
OSANAI, C.H. et al. Surto de dengue em Boa Vista, Roraima. Rev. Inst Med Trop São Paulo. 1983; 25 (1):53-4.

OSTERHOLM, M.T. et al. Efficacy and effectiveness of influenza vaccines: a systematic review and meta-analysis. Lancet Infect Dis. 2012 Jan;12(1):36-44. Epub 2011 Oct 25.

OSTERMAYER, A.L. et al. O inquérito nacional de prevalência de avaliação do controle da doença de Chagas no Brasil. Rev Soc Bras Med Trop 2011, 44(Supl2):108-121

PAN AMERICAN HEALTH ORGANIZATION (PAHO). Elimination of Neglected Diseases and Other Poverty-related Infections. Resolução aprovada no $49^{\circ}$ Conselho Diretor. Washington, 2009. Disponível em http://www2.paho.org/hq/dmdocuments/2009/CD49-09-e.pdf. Acessada em 15 abril 2013.

PASSOS, ADC. Epidemia de cólera no sul do Brasil. Cad Saúde Pública, 1999 15(2):426-27

PENNA, M.L.F. \& PENNA, G.O. Trend of case detection and leprosy elimination in Brazil. Trop Med Int Health 2007, 12(5):647-650.

PENNA, M.L.F; OLIVEIRA, M.L.W.R. \& PENNA, G. Spatial distribution of leprosy in the Amazon Region of Brazil. Emerging Infectious Diseases 2009, 15: 650-652.

PERNAMBUCO (Estado). SECRETARIA DE SAÚDE. Programa de Enfrentamento às Doenças Negligenciadas - SANAR. [dados não publicados].

PULLAN, R.L. et al. Human helminth co-infection: analysis of spatial patterns and risk factors in a Brazilian community. PLoS Neglected Tropical Diseases 2008, 2(12):e352.

QUADROS, R.M. et al. Parasitas intestinais em centros de educação infantil municipal de Lages — SC. Rev Soc Bras Med Trop 2004, 37(5): 422-23.

REICHENHEIM M.E. \& WERNECK G.L. Adoecer e morrer no Brasil dos anos 80: perspectivas de novas abordagens. In: GUIMARÃES R, TAVARES R. Saúde e Sociedade no Brasil anos 80. 1994. Rio de Janeiro: Relume-Dumará/ABRASCO/IMS-UERJ.

RENOINER, E.M. et al. Surto de toxoplasmose adquirida, Anápolis - GO. Boletim Eletrônico Epidemiológico 2007, 7(8):1-6.

SANTOS, A.A.M. O modelo brasileiro para controle das infecções hospitalares: após vinte anos de legislação, onde estamos e para onde vamos? Dissertação (Mestrado), UFMG, 2006. Disponível em http://portal/anvisa/gov/br/wps/portal/anvisa/home/servicosdesaude? cat=artigos.

SANTOS, J. Resposta brasileira ao controle da tuberculose. Rev Saúde Pública, 2007, 41(Supl.1): 89-94.

SASSON D. et al. Diferenças no perfil de mortalidade da população brasileira e da população usuária de planos de saúde. In: BRASIL, MINISTÉRIO DA SAƯDE. Saúde Brasil 2006: uma análise da situação de saúde no Brasil. Brasília, 2006, pp 120-133.

SÃO PAULO (Estado). Secretaria de Saúde. Centro de Vigilância Epidemiológica. Surto de Cyclosporacayetanensis investigado no Brasil, General Salgado - SP, 2000. Disponível em www. cve.saude.sp.gov.br/htm/hidrica/hidri_surto.atm, Acesso em 1 jul. 2011.

SÃO PAULO (Estado). Secretaria de Saúde. Centro de Vigilância Epidemiológica. Análise dos dados do Sistema de Vigilância Epidemiológica das Infecções Hospitalares do Estado de São Paulo, ano 2010. Disponível em www.cve.saude.sp.gov.br/htm/ih/pdf/ih11_dadops10.pdf. 
SÃO PAULO (Estado). Secretaria de Saúde. Centro de Vigilância Epidemiológica. Número de casos autóctones confirmados de esquistossomose no estado de São Paulo, 2011. Disponível em: www. cve.saude.sp.gov.br/htm/hídrica/hidri_estat.html. Acesso em: 23 jun. 2011.

SILVEIRA, A.C. \& DIAS, J.C.P. O controle da transmissão vetorial. Rev Soc Bras Med Trop 2011, 44(Supl 2):52-63.

SIQUEIRA, J.B. et al. Household survey of dengue infection in central Brazil: spatial point pattern analysis and risk factor assessment. Am J Trop Med Hyg 2004, 71:646-51.

TAUIL, P.L. Malária no Brasil, epidemiologia e controle. In BRASIL, MINISTÉRIO DA SAÚDE. Saúde Brasil 2009: uma análise da situação de saúde e da agenda nacional e internacional de prioridades em saúde. Brasília: Ministério da Saúde, 2010, pp 222-240.

TEIXEIRA, M.G. et al. Dynamics of dengue viruscirculation: a silent epidemic in a complex urban area. Trop Med Int Health 2002, 7: 757-62.

TEIXEIRA, M.G. et al. Dinâmica da circulação do vírus da dengue em uma área metropolitana no Brasil. Epidemiol Serv Saúde. 2003; 12: 87-97.

TEIXEIRA, M.G. et al. Dengue and dengue hemorrhagic fever epidemics in Brazil: what research is needed based on trends, surveillance and control experiences. Cad Saúde Pública. 2005; 21(5):1307-15.

TOSCANO C.M.; OLIVEIRA, W.K.; CARMO, E.H. Morbidade e mortalidade por doenças transmissíveis no Brasil. . In BRASIL, MINISTÉRIO DA SAÚDE. Saúde Brasil 2009: uma análise da situação de saúde e da agenda nacional e internacional de prioridades em saúde. Brasília: Ministério da Saúde, 2010, pp 73-110.

VASCONCELOS, P.F.C. et al. Epidemia de dengue em Fortaleza, Ceará: inquérito sorológico aleatório. Rev Saúde Pública. 1998; 32:447-54.

VASCONCELOS, P.F.C. et al. Inquérito soro-epidemiológico na ilha de São Luís durante epidemia de dengue no Maranhão. Rev Soc Bras Med Trop. 1999; 32:171-9.

VASCONCELOS, .PF.C. et al. Serious adverse events associated with yellow fever 17DD vaccine in Brazil: a report of two cases. Lancet 2001, 358:91-97.

VERAS, M.A.S.M. et al. Yellow fever vaccination coverage among children in Brazilian capitals. Vaccine 2010, 28:6478-6482.

VERAS, M.A.S.M. et al. The "AMA-Brazil" cooperative project: a nation-wide assessment of the clinical and epidemiological profile of AIDS-related deaths in Brazil in the antiretroviral treatment era. Cad Saúde Pública 2011, 27 (Supl 1):S104-S113.

VICTORA, C.G. et al. Falling diarrhea mortality in northeastern Brazil: did ORT play a role? Health Policy Plan 1996, 11:132-41.

XIMENES, R,A,A, et al. Multilevel analysis of hepatitis A in children and adolescents: a household survey in the Northeast and Central-Western regions of Brazil. Int J Epidemiol 2008, 37:852-861.

XIMENES R.A.A. et al. Methodology of a nationwide cross-sectional survey of prevalence and epidemiological patterns of hepatitis A, B and C in Brazil. Cad Saúde Pública 2010, 26: 16931704. 
WERNECK, G.L. et al. Multilevel modelling of the incidence of visceral leishmaniasis in Teresina, Brazil. Epidemiol Infect 2007, 135:195-200.

WORLD HEALTH ORGANIZATION (WHO). Lymphatic filariasis. 2000. Disponível em http://www. who.int/lymphatic_filariasis/disease/en/. Acesso em: 15 abr. 2013.

WORLD HEALTH ORGANIZATION (WHO). International Health Regulations 2005. $2^{\text {nd }}$ ed. Geneva: WHO, 2008, 82p.

WORLD HEALTH ORGANIZATION (WHO). Working to overcome the global impactof neglected tropical diseases. Geneva: WHO, 2010. 172 p.

WORLD HEALTH ORGANIZATION. Global tuberculosis control: WHO report 2011. Disponível em http://www.who.int/tb/publications/global_report/2011/gtbr11_full.pdf. Acesso em: mar. 2013.

ZACARÍAS, F. Eliminación de la sífilis congénita en América Latina y en el Caribe: marco de referencia para su implementación. Washington: PAHO, 2005. 